\title{
Effects of colostrum management on transfer of passive immunity and the potential role of colostral bioactive components on neonatal calf development and metabolism
}

\author{
A.J. Fischer-Tlustos, A. Lopez, K.S. Hare, K.M. Wood, and M.A. Steele
}

\begin{abstract}
Neonatal dairy and beef calves are required to ingest adequate volumes of high-quality colostrum during their first hours of life to acquire transfer of passive immunity (TPI). As such, immunoglobulin G (IgG) has largely been the focus of colostrum research over recent decades. Yet, little is known about the additional bioactive compounds in colostrum that potentially influence newborn calf development and metabolism. The purpose of this narrative review is to synthesize research regarding the effects of colostrum management practices on TPI, as well as to address the potential role of additional colostral bioactive molecules, including oligosaccharides, fatty acids, insulin, and insulin-like growth factor-I, in promoting calf development and metabolism. Due to the importance of IgG in ensuring calf immunity and health, we review past research describing the process of colostrogenesis and dam factors influencing the concentrations of IgG in an effort to maximize TPI. We also address the transfer of additional bioactive compounds in colostrum and prepartum management and dam factors that influence their concentrations. Finally, we highlight key areas of future research for the scientific community to pursue to ultimately improve the health and welfare of neonatal dairy calves.
\end{abstract}

Key words: immunoglobulin G, colostrogenesis, bioactive compounds, oligosaccharides, fatty acids.

Résumé : Les veaux laitiers et de boucherie nouveau-nés nécessitent la consommation d'un volume adéquat de colostrum de grande qualité au cours des premières heures de vie afin qu'il y ait transfert d'immunité passive. Par conséquent, l'immunoglobuline G (IgG) a grandement été l'objet des recherches sur le colostrum dans les décennies récentes. Par contre, il y a très peu de connaissances au sujet des autres composés bioactifs dans le colostrum qui pourraient potentiellement influencer le développement et le métabolisme du veau nouveau-né. Le but de cette revue narrative est de synthétiser la recherche sur les effets des pratiques de gestion du colostrum sur le transfert de l'immunité passive, ainsi que d'aborder le rôle potentiel des molécules additionnelles bioactives du colostrum, incluant les oligosaccharides, les acides gras, l'insuline et le facteur de croissance I qui s'apparente à l'insuline, dans la promotion du développement et du métabolisme des veaux. Vu l'importance des IgG pour assurer l'immunité et la santé des veaux, nous passons en revue les recherches passées qui décrivent le processus de colostrogénèse et les facteurs de la mère qui influencent les concentrations d'IgG dans un effort pour maximiser le transfert de l'immunité passive. Nous abordons aussi le transfert de composés bioactifs additionnels dans la gestion du colostrum et la gestion de fin de gestation, ainsi que les facteurs reliés à la mère qui influencent leurs concentrations. Finalement, nous soulignons les domaines clés de la recherche future que la communauté scientifique peut poursuivre afin d'arriver à améliorer la santé et le bien-être des veaux laitiers nouveau-nés. [Traduit par la Rédaction]

Mots-clés : immunoglobuline G, colostrogénèse, composés bioactifs, oligosaccharides, acides gras.

\section{Introduction}

Neonatal ruminants, including beef and dairy calves, can only acquire passive immunity through the absorption of immunoglobulins, specifically immunoglobulin G (IgG; Davis and Drackely 1998). The bovine cotyledonary synepithelial placenta is composed of three

Received 14 September 2020. Accepted 3 December 2020.

A.J. Fischer-Tlustos, ${ }^{*}$ A. Lopez, ${ }^{*}$ K.S. Hare, K.M. Wood, and M.A. Steele. Department of Animal Biosciences, Animal Science and Nutrition, University of Guelph, Guelph, ON N1G 1Y2, Canada.

Corresponding author: Michael Steele (email: masteele@uoguelph.ca).

*A.J. Fischer-Tlustos and A. Lopez are co-primary authors of this manuscript.

Copyright remains with the author(s) or their institution(s). Permission for reuse (free in most cases) can be obtained from copyright.com. 
maternal and three fetal layers, preventing the passive transfer of immunoglobulins to the calf in utero (Arthur 1996). As a result, the neonatal calf is born with a naïve immune system and depends on the feeding of adequate volumes [ $10 \%$ of body weight (BW), 3-4 L] of high-quality colostrum containing $\geq 50 \mathrm{~g}$ of $\operatorname{IgG} \cdot \mathrm{L}^{-1}$ and low bacterial $\left(<100 \quad 000 \mathrm{cfu} \cdot \mathrm{mL}^{-1}\right)$ and coliform $\left(<10000 \mathrm{cfu} \cdot \mathrm{mL}^{-1}\right)$ counts within the first $2 \mathrm{~h}$ of life (Weaver et al. 2000; Godden et al. 2019) to ensure successful transfer of passive immunity (TPI). In contrast, TPI in beef calves relies on timely voluntary consumption of colostrum. Beef calves typically voluntary consume approximately half of what a dairy calf would consume at first colostrum feeding (McGee and Earley 2019), and therefore, the greater IgG concentration in beef colostrum may be required to achieve successful TPI.

It is well known that TPI is crucial in preventing and reducing calf mortality and morbidity (Wells et al. 1996; Raboisson et al. 2016; Urie et al. 2018a) and promoting calf growth (Robison et al. 1988). Despite the importance of achieving TPI, failure of transfer of passive immunity (FTPI) remains relatively common on dairy farms. A recent cross-sectional study demonstrated that FTPI defined using the traditional serum total protein (STP) cut-point of $<5.2 \mathrm{~g} \cdot \mathrm{dL}^{-1}$ (Buczinski et al. 2018) - occurred in $24 \%$ of calves on Ontario dairy farms (Renaud et al. 2020). In addition, research in beef herds has demonstrated that approximately $16.1 \%$ and $19 \%$ of calves from western (Waldner and Rosengren 2009) and eastern (Filteau et al. 2003) Canada, respectively, experienced FTPI as classified using a FPTI threshold of $16 \mathrm{~g} \cdot \mathrm{L}^{-1}$ (Waldner and Rosengren 2009) and the traditional dairy FTPI threshold of $10 \mathrm{~g}$ of IgG per L (Filteau et al. 2003).

As highlighted above, TPI in dairy cattle has been traditionally defined as serum IgG concentrations $\geq 10 \mathrm{~g}$ of IgG per L or a STP value $\geq 5.2 \mathrm{~g} \cdot \mathrm{dL}^{-1}$ (Gay 1983; Tyler et al. 1996; Buczinski et al. 2018), whereas, in beef cattle production systems, thresholds for TPI are less described and have historically relied upon recommendations from dairy calves. Recent work in dairy calves (FurmanFratczak et al. 2011; Chigerwe et al. 2015) and a multitude of past research in beef calves (Dewell et al. 2006; Waldner and Rosengren 2009; Todd et al. 2018) have demonstrated that the traditional thresholds may not be adequate in defining TPI as a protective effect of serum IgG has been found at cut-points of $15 \mathrm{~g} \cdot \mathrm{L}^{-1}$ or greater. This suggests that FPTI, and its associated increased risk of morbidity and mortality, may affect a greater amount of dairy and beef calves than previously reported. Upon recent evaluation of the efficacy of current FPTI cut-off points, researchers demonstrated that no differences in mortality existed between calves with serum IgG concentrations $<10 \mathrm{~g}$. $\mathrm{L}^{-1}$ versus 10.0-17.9 $\mathrm{g} \cdot \mathrm{L}^{-1}$, further demonstrating that the current dichotomous standard for FPTI is ineffective at predicting mortality risk (Lombard et al. 2020). As such, Lombard et al. (2020) proposed the following serum IgG cut-point categories: excellent TPI $\left(>25.0 \mathrm{~g} \cdot \mathrm{L}^{-1}\right)$, good TPI (18.0-24.9 g. $\left.\mathrm{L}^{-1}\right)$, fair TPI (10.0-17.9 $\left.\mathrm{g} \cdot \mathrm{L}^{-1}\right)$, and poor TPI $\left(<10.0 \mathrm{~g} \cdot \mathrm{L}^{-1}\right)$ with the expectation that $>40 \%, \sim 30 \%$, $\sim 20 \%$, and $<10 \%$ of calves within each category, respectively, meet these standards at the herd level (Lombard et al. 2020). However, only 33 out of 103 US dairy herds met these recommendations from 2014 to 2015 (Lombard et al. 2020). Therefore, there will continue to be a further need to improve colostrum and newborn calf management to achieve or surpass the "good" cut-point category to meet new herd-level standards.

In addition to improving colostrum management in the dairy and beef sectors, there is a significant opportunity to improve colostrum quality itself. As previously mentioned, colostrum containing $\geq 50 \mathrm{~g} \cdot \mathrm{L}^{-1}$ of IgG is considered high quality (as reviewed by Godden 2008). Yet, colostral IgG content can widely vary, with colostrum collected from US dairy farms ranging from 7.1 to $159 \mathrm{~g} \cdot \mathrm{L}^{-1}$ and $16 \%$ of samples containing less than $50 \mathrm{~g} \cdot \mathrm{L}^{-1}$ (Quigley et al. 2013). Although beef cattle colostrum contains approximately 1.5 -fold greater concentrations of IgG than dairy cattle, there is also a tremendous variation in quality (approximately $50->200 \mathrm{~g} \cdot \mathrm{L}^{-1}$ ) and quantity ( $<1$ L to about 6 L; McGee and Earley 2019). There are various factors that affect colostral IgG concentrations in dairy cattle and beef cattle; which are further discussed. However, research pertaining to the influence of specific prepartum dam factors on colostrogenesis the process of colostrum formation - and ultimately the concentration of IgG in colostrum, is scarce.

Although colostrum and colostrogenesis research has largely focused on IgG, the benefits of colostrum feeding can also be attributed to bioactive factors that promote calf growth and development (Blum and Hammon 2000). In terms of macronutrients, fat accounts for the largest source of energy in colostrum, providing an estimated $63 \%$ of the digestible energy supply, whereas protein supplies an estimated $25 \%$ (K. Hare et al. unpublished data). Fat is essential in fueling the metabolism and mitigating thermoregulation of the newborn calf (Roy 1990; Quigley and Drewry 1998), and specific fatty acids (FA) that are elevated in colostrum (Contarini et al. 2014; O'Callaghan et al. 2020) can confer benefits on antioxidant status and immune response during initial weeks of life (Opgenorth et al. 2020b). Apart from the lipid fraction, colostrum contains up to $72 \times$ more oligosaccharides (OS) than whole milk (WM) (Fischer-Tlustos et al. 2020a). Bovine colostrum OS may accelerate the establishment of a healthy gut microbiome in newborn calves (Fischer et al. 2018a) and have been hypothesized to play a role in assisting in the intestinal uptake of IgG (Gill et al. 1999; Feeney et al. 2019). Furthermore, colostrum contains elevated levels of hormones, such as insulin (Blum and Hammon 2000) and insulin-like growth factor-I (IGF-I; Bühler et al. 1998; Jehle et al. 1999), both of which have positive effects on gastrointestinal cell proliferation and intestinal growth as discussed herein. 
Table 1. Levels of bioactive molecules in colostrum (milking 1) compared with whole milk ${ }^{a}$ and their proposed functions.

\begin{tabular}{|c|c|c|c|}
\hline Bioactive compound & Colostrum & Whole milk & Proposed function \\
\hline $\operatorname{IgG}\left(g \cdot L^{-1}\right)$ & 94.1 & 1.2 & Passive immunity \\
\hline Neu5Ac-glycosylated IgG $(\mu \mathrm{M})$ & $\sim 1150$ & $\sim 210$ & Facilitating intestinal uptake of IgG \\
\hline Fat (\%) & 5.7 & 4.3 & Energy, thermoregulation \\
\hline Fat $\left(\mathrm{g} \cdot \mathrm{kg}^{-1}\right)$ & 62.9 & 41.8 & Energy, thermoregulation \\
\hline$\omega-3$ FA (\%) & 0.63 & 0.35 & Immune modulation, antioxidant capacity \\
\hline IGF-I $\left(\mu \mathrm{g} \cdot \mathrm{L}^{-1}\right)$ & 310 & $<2$ & Intestinal development \\
\hline Insulin $\left(\mu \mathrm{g} \cdot \mathrm{L}^{-1}\right)$ & 65 & 1 & Promote postnatal growth, gut development \\
\hline $3^{\prime} \mathrm{SL}\left(\mu \mathrm{g} \cdot \mathrm{mL}^{-1}\right)$ & 592.4 & 41.2 & Prebiotic, immune modulation, pathogen inhibition \\
\hline Nucleotides $\left(\mu \mathrm{mol} \cdot \mathrm{dL}^{-1}\right)$ & 258.7 & 15.6 & Immune function, gastrointestinal development \\
\hline $5^{\prime} \mathrm{UMP}\left(\mu \mathrm{mol} \cdot \mathrm{dL}^{-1}\right)$ & 18.63 & 2.92 & Modulation of immune function \\
\hline miRNA (total No.) & 102 & 53 & Gastrointestinal development, immune modulation \\
\hline
\end{tabular}

Note: Neu5Ac, 5-N-acteylneuraminic acid; FA, fatty acid; IGF-I, insulin-like growth factor-I; 3'SL, 3'sialyllactose; 5’UMP, uridine 5'monophosphate; miRNA, microRNA.

${ }^{a} \operatorname{IgG}$, fat (\% and g. $\mathrm{kg}^{-1}$ ), and $3^{\prime}$ SL are reported in Fischer-Tlustos et al. (2020a); Neu5Ac-glycosylated IgG is reported in Takimori et al. (2011); $\omega-3$ FA \% is reported in Hare et al. (2019a); IGF-I and insulin concentrations are reported in Blum and Hammon (2000); nucleotide concentrations are reported in Gill et al. (2011); total number of miRNA is reported in Izumi et al. (2012).

Research elucidating the effects of colostral nutritive and bioactive factors, beyond IgG, on newborn calf development and health, and the prepartum dam factors that influence their transfer and (or) production in the bovine mammary gland, is scarce. For this reason, this narrative review will encompass a summary of the current literature describing the process of colostrogenesis, pertaining to IgG, and colostrum management practices that ensure TPI, as well as the effects of nutritional and bioactive compounds in colostrum on the neonatal calf and dam factors that may influence their transfer to and (or) synthesis in the bovine mammary gland.

\section{Immunoglobulin G}

\section{Colostrogenesis: immunoglobulin G transfer into colostrum}

Colostrogenesis is the process of colostrum formation in the mammary gland (Baumrucker and Bruckmaier 2014). It has also been stated that colostrogenesis is the process where immunoglobulins, specifically, are transferred from the cow's circulation into the mammary gland (Barrington et al. 2001). Bovine colostrum composition is not constant among cows and varies greatly in IgG concentration (Kehoe et al. 2007; Morrill et al. 2012), nutritional components (Kehoe et al. 2007), and bacteria content (Elizondo-Salazar and Heinrichs 2009). Colostrum has a unique composition and one of its major differences compared with mature milk has been attributed to its greater IgG concentration (Table 1; Barrington et al. 2001). Colostrum has an average IgG concentration of $50-70 \mathrm{~g} \cdot \mathrm{L}^{-1}$, accounting for $70 \%-80 \%$ of total protein (Barrington et al. 2001), whereas mature milk has an IgG concentration range of $1.2-3.3 \mathrm{~g} \cdot \mathrm{L}^{-1}$ (Whitney et al. 1976). In contrast, colostrum has low IgM and IgA concentrations $\left(3.0\right.$ and $0.4 \mathrm{~g} \cdot \mathrm{L}^{-1}$, respectively; Butler 1994). Various results from Kehoe et al. (2007), Swan et al. (2007), Baumrucker et al. (2010), and Morrill et al. (2012) have reported a substantial variation in mean colostrum IgG concentrations in dairy cows (34.96, 76.7, 37.5, and 68.6 g.L $\mathrm{L}^{-1}$; respectively).

\section{Timing of colostrogenesis}

It is known that bovine colostrum is produced and accumulated during late pregnancy (Baumrucker and Bruckmaier 2014). Colostrum formation occurs during Lactogenesis I, which is the event in which cells in the mammary gland differentiates and changes from a non-secretory to a secretory status (Tucker 1981). Lactogenesis I is part of the various differentiation processes that occur during lactation, including Lactogenesis I (differentiation), Lactogenesis II (lactation), and involution (Baumrucker and Bruckmaier 2014). However, the exact time of colostrogenesis onset is unknown as various reports state that it may begin from 3 to $7 \mathrm{wk}$ prior to calving (Brandon et al. 1971; Sasaki et al. 1976; Barrington et al. 2001).

Immunoglobulin $G_{1}$ and $G_{2}$ transferred to colostrum are derived from maternal circulation (Fig. 1A; Butler 1983), and it has been reported that IgG transport begins weeks prior to parturition and peaks 1-3 d before calving (Brandon et al. 1971; Sasaki et al. 1976). Recently, Baumrucker and Bruckmaier (2014) attempted to quantify colostrogenesis as beginning when IgG concentrations in mammary secretions are greater than IgG concentrations in maternal circulation. The decreased IgG concentration in the dam's serum in comparison with its mammary secretion occurs at different times prior to parturition among animals (Baumrucker and Bruckmaier 2014), which could partially account for the distinct ability of specific animals to produce higher 
Fig. 1. A schematic of the synthesis and (or) transfer of specific bioactive compounds in the bovine mammary gland and their absorption and effects in the neonatal calf enterocyte as created using Adobe Illustrator (CC 2018). (A) Synthesis of sialylated oligosaccharides (Huizing 2005; Smilowitz et al. 2014), fatty acids (reviewed in Bauman and Griinari 2003), and transport of immungloublin G (Butler 1983; Ollivier-Bousquet 1998), insulin (Malven et al. 1987), and IGF-I (Malven et al. 1987; Prosser et al. 1991; Weber 2012) in the bovine mammary gland and their transport into bovine colostrum. (B) Absorption and effects of colostral oligosaccharides (Gill et al. 1999; Martin et al. 2002; Marbocal et al. 2010, 2011; Yu et al. 2013), IgG (Cervenak and Kacskovics 2009; Tzaban et al. 2009), insulin (Pierce et al. 1964; Shulman 1990; Huo et al. 2006; Kirovski et al. 2008), IGF-I (Roffler et al. 2003; Pyo et al. 2020), and fatty acids [Gooden et al. 1971; De Santis et al. 2015 (review paper)] in the neonatal calf intestine. Dashed arrows represent proposed mechanisms/pathways, and solid arrows represent mechanisms/pathways that are well established. CMP, cytidine monophosphate; OS, oligosaccharide; SA, sialic acid; ST, sialyltransferase; IgG, immunoglobulin G; FcR, Fc receptor; INS, insulin; INSR, insulin receptor; IGF-I, insulin-like growth factor-I; IGF-IR, insulin-like growth factor-I receptor; FA, fatty acid; NEFA, non-esterified fatty acid; TG, triglyceride; LPL, lipoprotein lipase; MFG, milk fat globule.

A

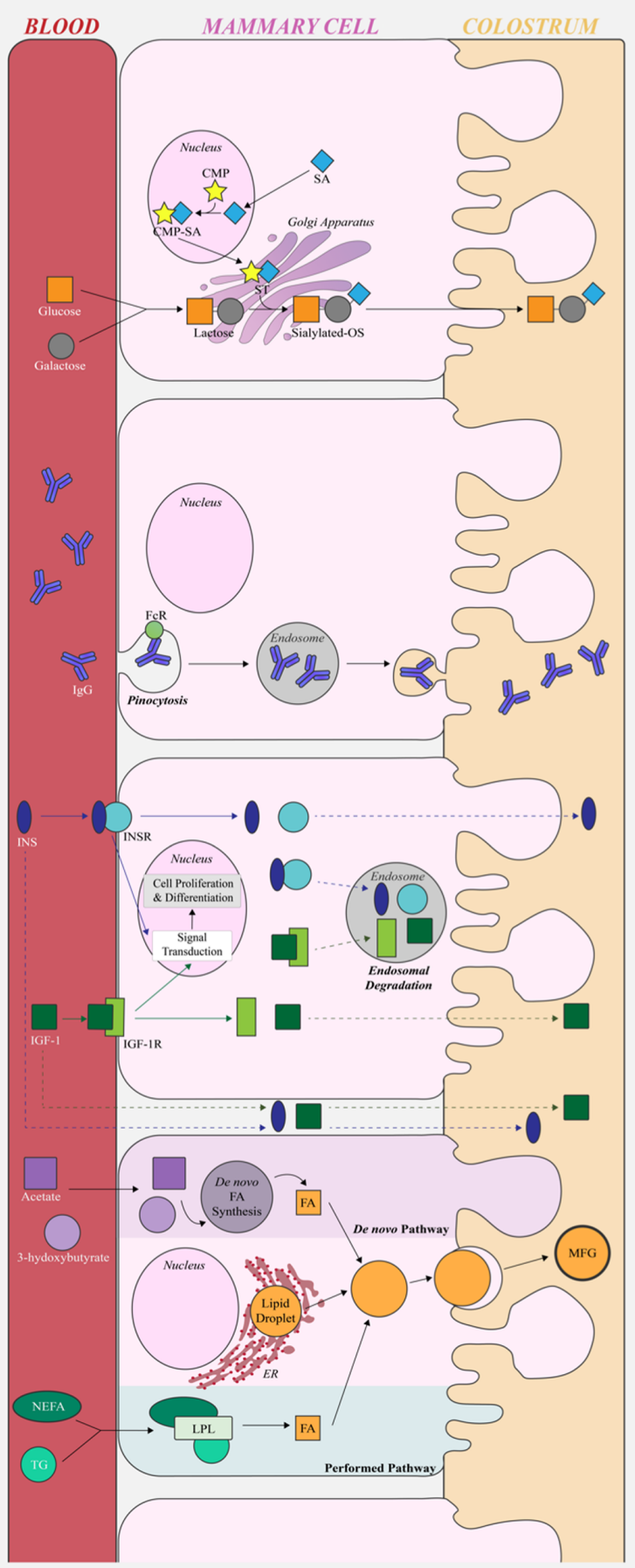

B

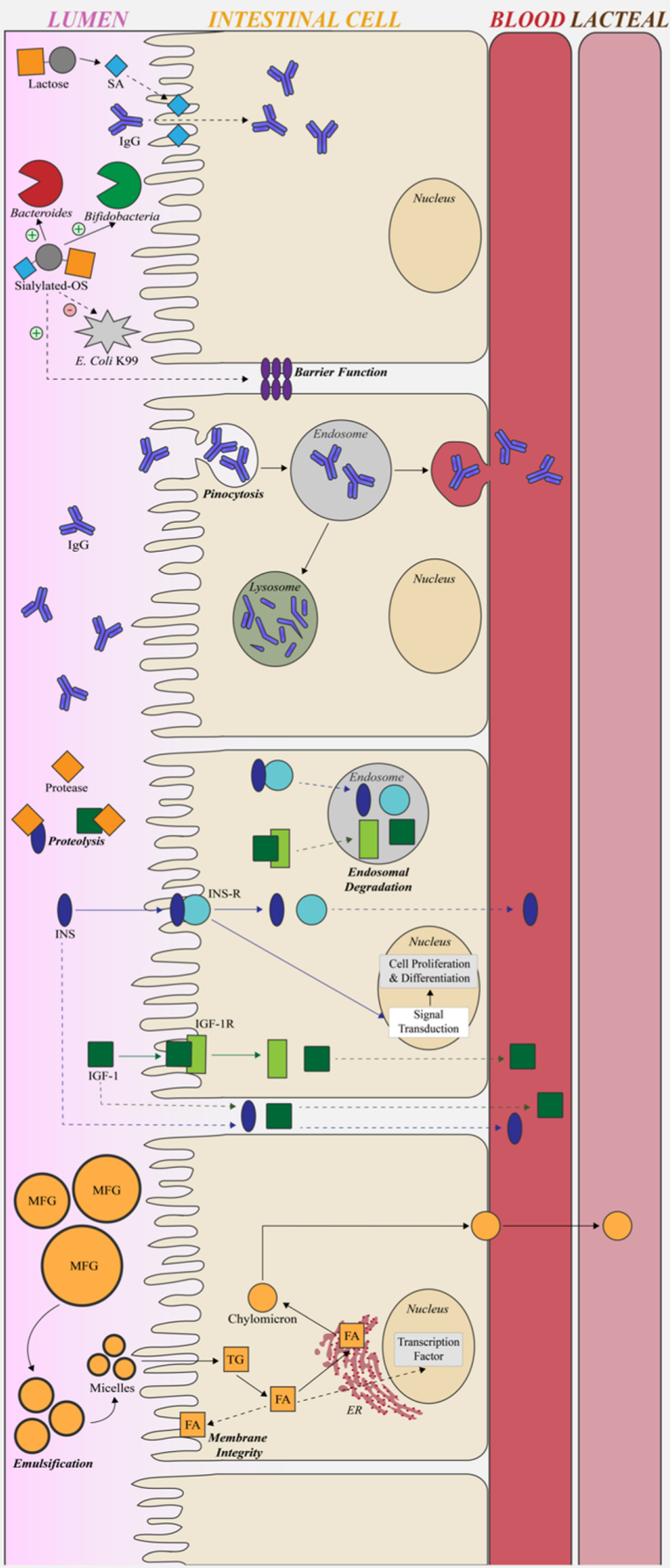


amounts of colostral IgG (Kehoe et al. 2007; Baumrucker et al. 2010). It is thought that $\operatorname{IgG}_{1}$ transfer into the mammary secretory lumen occurs by the receptor complex known as the neonatal crystallizable fragment receptor (FcRn; Baumrucker and Bruckmaier 2014), and that transcytosis is responsible for the mass appearance of $\mathrm{IgG}_{1}$ in colostrum (Fig. 1A; Ollivier-Bousquet 1998). Specifically, FcRn are located within endosomes in which attachment and transport of $\operatorname{IgG}_{1}$ molecules occurs (Baumrucker and Bruckmaier 2014). Thereafter, colostral $\mathrm{IgG}_{1}$ is transferred to the neonate by intestinal cells binding to $\operatorname{IgG}_{1}$ molecules and forming an endosome, which is transcytosed to the apical side of the cell (Fig. 1B; Tzaban et al. 2009; Baumrucker and Bruckmaier 2014).

\section{Factors influencing colostrogenesis and colostrum composition}

Various factors affect colostrum composition, yet, most research focuses specifically on IgG concentration or IgG mass. Few studies, such as Dunn et al. (2017), have characterized the factors that affect colostrum components apart from IgG concentration, including fat, protein, and lactose concentration. Colostrum composition in dairy cattle is affected by parity, dry period length, colostrum volume, breed (Weaver et al. 2000), vaccination protocols (Dunn et al. 2017), disease exposure, diet (Mann et al. 2016), individual variation (Parrish et al. 1950), colostrogenesis onset (Baumrucker and Bruckmaier 2014), individual farm variation (Gulliksen et al. 2008), systematic and endocrine regulation (Guy et al. 1994a, 1994b). Whereas factors previously associated with colostrum composition in beef cattle are breed, parity, and body condition score (reviewed by McGee and Earley 2019).

A multitude of management practices have been associated with differences in colostral IgG concentration. Controlled studies have largely found no differences in dry period length (i.e., a short, $<6$ wk dry period compared with a conventional, $\sim 8 \mathrm{wk}$ dry period) on colostrum quality (Klusmeyer et al. 2009; Shoshani et al. 2014) and serum IgG concentrations of calves (Mayasari et al. 2015; O’Hara et al. 2019). However, Morrill et al. (2012) determined that dam parity can have a large influence on colostral IgG concentrations, with reported mean colostrum IgG concentrations for first, second, and third parity dams of $42.4,68.6$, and $95.9 \mathrm{~g} \cdot \mathrm{L}^{-1}$, respectively. Yet, Morrill et al. (2012) did not find differences in IgG concentration among breeds and reported similar mean colostral IgG values for Holstein and Jersey cows of 74.2 and $65.8 \mathrm{~g} \cdot \mathrm{L}^{-1}$, respectively. Producing large volumes of colostrum likely dilutes the colostrum IgG concentration (Guy et al. 1994a), an affect that may also attribute to the variation in colostral IgG when colostrum is collected at differing times following parturition (Baumrucker et al. 2010). Yet, Quigley et al. (1994) found that volume and IgG concentration were not correlated in colostrum from Jersey cattle. However, the possible negative relationship between colostrum volume and colostral IgG concentration could be the result of the onset of Lactogenesis II during parturition (Quigley and Drewry 1998). If Lactogenesis II occurs around parturition, milk may begin accumulating in the udder and consequently dilute colostrum and its IgG concentration (Guy et al. 1994b; Winger et al. 1995). Although the factors controlling colostrum yield are not well understood, it is pertinent to determine dry cow management strategies that maximize colostrum yield while maintaining adequate IgG concentrations to ensure TPI in neonatal calves.

Existing management, environmental, and nutritional factors associated with colostrum composition have been reported throughout previous years, but strategic interventions that enhance colostrum composition have not yet been employed. There is clear evidence that colostrum varies among cows, farms, and geographical regions; as a result, there must be specific factors or metabolic components controlling this degree of variation. Specific experiments researching individual factors and their potential role in altering composition are needed. In addition, it is known that changes in the nutrition and management practices during the dry period affect overall colostrum composition, but the specific mechanisms controlling the appearance of distinct colostral immune and bioactive components is not clear.

\section{Ensuring transfer of passive immunity}

The transfer of immunoglobulins is mainly composed of two molecular processes: (1) maternal: secretion and concentration of IgG in colostrum, and (2) offspring: transport of absorbed intestinal IgG into the systemic circulation and tissues of the neonatal calf (Figs. 1A, 1B; Besser and Gay 1994). Specifically, immunoglobulins are absorbed in the small intestine (Bush and Staley 1980); however, whether this process is a specific, receptormediated process, or unspecific remains controversial. For decades, it was assumed that intestinal IgG absorption occurred via non-specific pinocytosis, in which intestinal cells at the basal side of the intestinal cell enclose and form an endosome containing IgG molecules (Cervenak and Kacskovics 2009; Tzaban et al. 2009) and are thereafter transported to the calf's blood stream through the thoracic duct (Besser and Gay 1994). In rats and humans, intestinal IgG absorption occurs via a specific receptor-mediated process via FcRn (Simister and Rees 1985; Shah et al. 2003). In neonatal calves, research has provided evidence of a specific, receptor-mediated intestinal transport of IgG carried out by specialized vesicles (Jochims et al. 1994); yet, whether this process occurs via FcRn remains to be elucidated. However, the rate of IgG transfer into peripheral circulation can be affected by time at first feeding (Fischer et al. 2018b), mass of IgG consumed (Quigley and Drewry 1998), and level of colostrum bacterial contamination (Gelsinger et al. 2015; Saldana et al. 2019). 


\section{Quantity, quality, and quickness of colostrum feeding}

It is recommended to feed newborn dairy calves $4 \mathrm{~L}$ of colostrum containing an IgG concentration $>50 \mathrm{~g} \cdot \mathrm{L}^{-1}$ or at $10 \%-12 \%$ of birth BW (as reviewed by Godden et al. 2019). Currently, colostrum feeding practices among studies are not constant, as some studies feed calves according to a specific volume: 4 L (Lago et al. 2018; Saldana et al. 2019) or 3 L (Mokhber-Dezfooli et al. 2012; Desjardins-Morrissette et al. 2018); or as a proportion of calf BW (Fischer et al. 2018b; Hare et al. 2020). Feeding a specific amount to all calves has been controversial, as it has been stated that feeding large amounts of colostrum can slow the emptying rate of colostrum from the abomasum, which could reduce IgG absorption due to increased time to reach the site of absorption in the small intestine (Mokhber-Dezfooli et al. 2012). It is also hypothesized that feeding larger amounts of colostrum or a high total IgG mass could comprise the apparent efficiency of absorption (AEA) of colostral IgG (Lopez et al. 2020). Conneely et al. (2014) fed calves different volumes of colostrum at $7 \%, 8.5 \%$, or $10 \%$ of birth BW. The authors reported that calves fed colostrum at $8.5 \%$ of birth BW achieved the greatest serum IgG concentration at $24 \mathrm{~h}$, as well as the greatest AEA compared with calves fed at $7 \%$ or $10 \%$ of BW. However, colostrum IgG concentrations in this study were not standardized among treatment groups and on average ranged from 100.3 \pm 43.5 (mean \pm standard deviation) to $120.4 \pm 47.2 \mathrm{~g} \cdot \mathrm{L}^{-1}$ (Conneely et al. 2014). In addition, two thirds of calves were provided with more IgG by feeding transition milk (IgG content not reported) anywhere from 3 to $20 \mathrm{~h}$ postnatal ( $56 \%$ of calves $>12 \mathrm{~h}$ ). The findings from Lopez et al. (2020) and Conneely et al. (2014) suggest a possible physiological limit to the amount of IgG that can be absorbed by enterocytes, likely due to the saturation of IgG receptors (Leece 1973; Jaster 2005); however, further research utilizing a pooled source of maternal colostrum with a standardized IgG concentration fed at different volumes is required to determine if this physiological phenomenon of "gut saturation" occurs. Yet, it is important to note that more than $80 \%$ of US producers do not measure the quality of colostrum (Urie et al. 2018b) on farm. To ensure that calves do not experience FPTI and its associated effects, especially when average or lowquality colostrum may unknowingly be used, it is recommended that calves are consistently fed 3-4 L ( 10\% BW) of colostrum (see review by Godden et al. 2019). Small calves (i.e., Jersey calves or Holstein calves $<30 \mathrm{~kg} \mathrm{BW}$ ) should be fed two meals of colostrum based on BW ( $\sim 2$ to $3 \mathrm{~L}$ per meal) within the first $12 \mathrm{~h}$ of life, with producers ensuring that colostrum IgG concentration is $>50$ g. $\mathrm{L}^{-1}$ (Jaster 2005).

In addition to considering the volume fed to a calf, colostrum IgG concentration must be considered equally because the total IgG mass consumed is the determining factor in circulating serum IgG concentration at $24 \mathrm{~h}$. Maternal colostrum quality is based on its IgG concentration (reviewed by Godden 2008). Recently, Lombard et al. (2020) concluded that the threshold to determine colostrum quality should remain at $\geq 50 \mathrm{~g} \cdot \mathrm{L}^{-1}$, as previously defined in a review by McGuirk and Collins (2004). In addition to adequate IgG concentration, highquality colostrum can also be defined as colostrum containing total bacteria and coliform counts $<100000$ and $<10000 \mathrm{cfu} \cdot \mathrm{mL}^{-1}$, respectively (reviewed by McGuirk and Collins 2004). The impact of bacterial counts on TPI has been researched (Gelsinger et al. 2014; Gelsinger et al. 2015; Saldana et al. 2019), and it is hypothesized that high bacterial counts may interfere with immunoglobulin absorption (Corley et al. 1977; James et al. 1981; Gelsinger et al. 2014). Research has concluded that heat treatment of colostrum at $60{ }^{\circ} \mathrm{C}$ for $30-60 \mathrm{~min}$ to reduce its bacterial count does not affect colostral IgG concentrations but positively affects IgG absorption (Godden et al. 2012; Gelsinger et al. 2014; Armengol and Fraile 2016), as well as reduces the incidence of morbidity and mortality (Godden et al. 2012; Armengol and Fraile 2016). However, a 2018 study reported that only 5\% of Canadian dairy operations feed heat-treated colostrum, despite its well-known benefits of reducing harmful bacterial counts and improving TPI (Winder et al. 2018).

Along with colostrum quality and quantity, the quickness of first colostrum feeding is a primary factor influencing the degree of TPI as enterocytes lose the ability to absorb intact macromolecules as time after birth increases (Staley and Bush 1985). In 2014, Osaka et al. found that calves fed colostrum within the first hour of life, from 1 to $6 \mathrm{~h}$ or 6 to $12 \mathrm{~h}$ of life did not differ in serum IgG concentrations. The authors concluded that AEA in the initial hours of life is influenced to a greater extent by mass of IgG rather than age at first colostrum feeding. However, colostrum intake widely varied among calves (1.5-5.2 L) and colostral IgG concentrations were not standardized (Osaka et al. 2014). Recently, Fischer et al. (2018b) fed calves pooled colostrum (62 g of $\left.\operatorname{IgG} \cdot \mathrm{L}^{-1}\right)$ at $7.5 \%$ of birth BW ( 200 $\mathrm{g}$ of IgG total) either within the first hour of life, at $6 \mathrm{~h}$ or at $12 \mathrm{~h}$ of life and demonstrated that calves fed within the first hour of life had the greatest serum IgG concentrations and AEA compared with calves fed at 6 and $12 \mathrm{~h}$. Contrary to expectations, serum IgG and AEA were not different between calves fed at 6 and $12 \mathrm{~h}$. Despite the discrepancies between studies, industry recommendations typically state to feed colostrum within 1-2 h after birth (Godden et al. 2019). However, further research is needed to determine the calf and environmental factors that influence gut closure over the first $12 \mathrm{~h}$ of life to implement optimal colostrum management strategies that increase the chances of achieving successful TPI.

\section{Additional considerations: feeding method and extended colostrum feeding}

The quantity, quality, and quickness of colostrum feeding are among the most common factors considered 
in proper colostrum management practices. However, United States Department of Agriculture-National Animal Health Monitoring System (USDA-NAHMS) research has clearly demonstrated that additional factors can impact TPI (Shivley et al. 2018). Godden et al. (2009) was the first controlled study to investigate the effect of feeding method on TPI, demonstrating that feeding $1.5 \mathrm{~L}$ (100 $\mathrm{g}$ of IgG) of colostrum replacer (CR) via esophageal tube or nipple bottle resulted in FPTI rates of $58.3 \%$ and $0 \%$, respectively. However, feeding $3 \mathrm{~L}$ (200 g of IgG) of CR via esophageal tube or nipple bottle resulted in no differences in TPI (Godden et al. 2009) as corroborated by Desjardins-Morrissette et al. (2018). Similarly, Bonk et al. (2016) found no differences between feeding methods when $3.5 \mathrm{~L}$ of pooled, maternal colostrum was fed to calves. Researchers have suggested that feeding small volumes of colostrum or CR via an esophageal tube causes a delay in a large proportion of the meal, and consequently IgG, reaching the small intestine (Godden et al. 2009; Sharifi et al. 2009). Indeed, feeding $3 \mathrm{~L}$ of CR by either nipple bottle or tube feeding did not alter the rate of abomasal emptying, confirming that a delay in abomasal emptying does not occur when moderate $(\sim 3 \mathrm{~L})$ volumes are fed (Desjardins-Morrissette et al. 2018). At the population level, feeding colostrum via esophageal tube and nipple bottle is associated with FPTI rates of $9 \%$ and $14 \%$, respectively (Shivley et al. 2018), indicating that the risk of FPTI may be reduced when esophageal tube feeding colostrum is consistently practiced. Esophageal tube feeding is an efficient, appealing strategy as it only takes $\sim 1$ to 5 min to feed $3 \mathrm{~L}$ of colostrum compared with bottle feeding, which requires an average of 18 min per meal (K. Hare et al. unpublished data; Desjardins-Morrissette et al. 2018). It may be possible that esophageal tube feeding allows for a more timely and consistent delivery of colostrum compared with feeding via nipple bottle, thus conferring benefits on FPTI rates at the population level. Yet, as controlled studies have shown no differences in serum IgG concentrations via esophageal tube or bottle feeding, either feeding method can be used to ensure adequate passive transfer when $>3 \mathrm{~L}$ of colostrum is fed within the first hours of life.

Multiple studies have also demonstrated that providing a second colostrum feeding can increase serum IgG concentrations (Stott et al. 1979; Morin et al. 1997; Halleran et al. 2017; Hare et al. 2020). Halleran et al. (2017) fed calves one $4 \mathrm{~L}$ meal of colostrum within $4 \mathrm{~h}$ of birth or $3.7 \mathrm{~L}$ within $4 \mathrm{~h}$, followed by $1.9 \mathrm{~L}$ prior to $12 \mathrm{~h}$ of birth. The authors demonstrated that calves fed two colostrum meals had markedly higher serum IgG concentrations $\left(39.5 \pm 1.7 \mathrm{~g} \cdot \mathrm{L}^{-1}\right)$ compared with their one meal counterparts $\left(23.5 \pm 1.3 \mathrm{~g} \cdot \mathrm{L}^{-1}\right)$. Recently, Hare et al. (2020) standardized the amount of pooled, maternal colostrum fed $(7.5 \% \mathrm{BW})$ to all calves at $2 \mathrm{~h}$ postnatal, after which calves were fed subsequent meals of either pooled, maternal colostrum or WM at $5 \% \mathrm{BW}$ at $12 \mathrm{~h}$ intervals for $3 \mathrm{~d}$ of life. Calves fed subsequent meals of colostrum had greater maximum serum IgG concentrations $\left(30.4 \pm 0.8 \mathrm{~g} \cdot \mathrm{L}^{-1}\right)$ compared with calves fed WM $\left(23.9 \pm 0.8 \mathrm{~g} \cdot \mathrm{L}^{-1}\right)$. Despite all calves achieving successful TPI as defined by the traditional serum IgG cut-point of $10 \mathrm{~g} \cdot \mathrm{L}^{-1}$, providing colostrum after $24 \mathrm{~h}$ of life conferred little additional benefit to increasing serum IgG concentrations. Thus, although providing colostrum after $24 \mathrm{~h}$ is an inefficient strategy to improve TPI, the authors suggest a minimum of one additional meal of colostrum should be provided within $12 \mathrm{~h}$ of the initial colostrum meal to increase serum IgG (Hare et al. 2020). Yet, it is important to note that serum IgG concentrations do not differ among calves fed 191.4 $\mathrm{g}$ of IgG in a single meal at $45 \mathrm{~min}$ of life compared with calves fed the same total IgG mass split over two meals ( 120 g of IgG at $45 \mathrm{~min}$ and $\sim 65 \mathrm{~g}$ of IgG at $6 \mathrm{~h}$; Cabral et al. 2012, 2014). This implies that studies in which positive effects on TPI were observed (Stott et al. 1979; Morin et al. 1997; Halleran et al. 2017; Hare et al. 2020) may be largely due to differences in total IgG mass consumed.

In summary, it is important to consider the method for colostrum feeding used depending on the colostrum volume fed. In dairy calves, $3 \mathrm{~L}$ of colostrum containing $>50 \mathrm{~g}$ of IgG. $\mathrm{L}^{-1}$ is the minimum volume to be consumed in the first hours of life via either esophageal tube or nipple bottle. As well, it is fundamental to ensure that colostrum is being fed during the first hours of life when the gut in hyperpermeable to IgG; however, providing a second high-quality colostrum meal within $12 \mathrm{~h}$ of the initial meal may confer additional benefits to TPI. To improve colostrum quality through reduced bacterial contamination, heat-treatment of colostrum is a practice that should be further considered by dairy producers.

\section{Colostral bioactive components}

In this review, colostral bioactive components are defined as compounds or molecules (apart from nutrients) that are present in colostrum in micro quantities that stimulate physiological responses systemically or locally within the gastrointestinal tract of the neonate. Although there is an abundance of bioactive compounds in bovine colostrum (see reviews by Blum and Hammon 2000; McGrath et al. 2016), this review will focus specifically on the potential bioactivity of OS, fatty acids, hormones belonging to the insulin-relaxin superfamily, unique classes of proteins within the colostrum proteome, microRNAs, and nucleotides, on calf development.

\section{Oligosaccharides and sialic acid}

Bovine OS are small polymers of simple sugars that largely consist of a lactose backbone elongated by one or more sialic acid residues and are present at high concentrations in colostrum $\left(\sim 1.0 \mathrm{~g} \cdot \mathrm{L}^{-1}\right)$ compared with WM $\left(<0.2 \mathrm{~g} \cdot \mathrm{L}^{-1}\right.$; Nakamura et al. 2003; Fischer-Tlustos et al. 2020a). Sialic acids are a family of more than 50 structurally different nine-carbon sugars, with the most 
abundant being 5-N-acteylneuraminic acid (Neu5Ac) and 5-N-glycolneuraminic acid (Peri et al. 2018). When subjected to neuraminidase treatment, bovine colostrum contains $27-34 \mathrm{nmol} \cdot \mathrm{mL}^{-1}$ of Neu5Ac and 1.2-2.7 $\mathrm{nmol} \cdot \mathrm{mL}^{-1}$ of 5-N-glycolneuraminic acid, demonstrating that Neu5Ac is the prominent sialic acid in bovine colostrum (Vicaretti et al. 2018). There are four primary Neu5Ac-containing OS present at significant concentrations in colostrum, including $3^{\prime}$ sialyllactose ( $\left.3^{\prime} \mathrm{SL}\right)$, 6'sialyllactose, 6'sialyllactosamine, and disialyllactose (Martin-Sosa et al. 2003; Tao et al. 2009; Fischer-Tlustos et al. 2020a). Among these four primary OS in colostrum, 3'SL accounts for over $55 \%$, whereas 6 'sialyllactose, disialyllactose, and 6'sialyllactosamine only account for $10 \%$, $22 \%$, and $13 \%$, respectively (Fischer-Tlustos et al. 2020a). However, recent research has identified up to 62 different colostrum and milk OS resolvable by capillary electrophoresis, including sulfate-, N-acetylglucosamine-, and fucose-containing OS, albeit present at low concentrations in colostrum (Vicaretti et al. 2018; FischerTlustos et al. 2020b). Yet, the concentrations of specific OS required to evoke physiological responses, as discussed below, in the neonatal calf is currently unknown.

Recently, a wide array of research has been conducted in regard to the beneficial effects that human milk OS have on infant health and physiology (as reviewed by Zivkovic et al. 2011; Plaza-Diaz et al. 2018). Specifically, promoting the growth and development of the intestinal microbiota is one of the most well-established roles of human milk OS in newborn infants (Zivkovic et al. 2011). In contrast, the potential role of bovine colostrum in promoting the initial establishment and subsequent development of the calf intestinal microbiome has only recently been characterized (Malmuthuge et al. 2015; Fischer et al. 2018b; Ma et al. 2019; Song et al. 2019). Importantly, moderate correlations have been observed between colostrum OS and the beneficial bacteria, Bifidobacterium, in the small intestine of calves within the first $12 \mathrm{~h}$ of life, suggesting that bovine colostrum OS may be important in establishment of the calf intestinal microbiome (Fischer et al. 2018a). In addition to Bifidobacteria (Yu et al. 2013), species belonging to the genus Lactobacillus can utilize OS monosaccharide units, including glucose and galactose, and possibly trisaccharide OS to promote their growth (Schwab and Ganzle 2011; Boudry et al. 2017), whereas Bacteroides uniquely cleave and catabolize sialic acid residues (Marcobal et al. 2010; Marcobal et al. 2011), possibly conferring a selective advantage for this beneficial bacterial genus within the neonatal calf gastrointestinal tract (GIT) (Fig. 1B).

Promoting the establishment of a balanced neonatal microbiome is only one of multiple proposed functions of colostrum OS. In vitro research has demonstrated that OS can act as "pathogenic decoys", as they contain structural moieties similar to cell surface glycoconjugates utilized in cell recognition by bacterial fimbriae, thus inhibiting the adhesion of pathogens to host target cells
(Karlsson 1995; Fernandez and Berenguer 2000). Interestingly, bovine colostrum and milk OS are inefficient at inhibiting human colonization factor antigenfimbriated enterotoxigenic Escherichia coli (Martin-Sosa et al. 2002), but they are highly efficient at inhibiting K99-fimbriated enterotoxigenic E. coli isolated from more than $80 \%$ of diarrheic samples from calves (Fig. 1B; Martin et al. 2002). This suggests that an evolutionary mechanism may be responsible for the secretion of OS specific to pathogens commonly encountered during early life to prevent infection in the young calf. Recent work has also demonstrated that bovine IgG is highly glycosylated with sialic acid, specifically Neu5Ac, with Neu5Ac glycosylation being highest in colostrum and undetectable in milk at $10 \mathrm{~d}$ postpartum (Table 1; Feeney et al. 2019). Furthermore, desialylation of neonatal rat microvillus membranes by neuraminidase treatment reduced the binding of IgG by $42 \%$ (Fig. 1B; Gill et al. 1999). Similar to calves, rat pups acquire passive immunity postnatally through the ingestion of colostrum and milk IgG (Pentsuk and van der Laan 2009). Collectively, this research further suggests an evolutionary reasoning for high levels of sialic acid-containing OS in the colostrum of species that require postnatal TPI via colostrum to establish an innate immune system. In addition to the aforementioned beneficial effects, the supplementation of bovine OS in mice fed an unhealthy Western diet ( $40 \%$ fat, $16 \%$ protein, and $44 \%$ carbohydrates) partially restored the diversity of the gut microbiota, fully reversed impairments of colonic barrier function and normalized levels of the inflammatory marker TNF- $\alpha$ compared with those fed only a Western diet (Boudry et al. 2017). These findings have significant implications in young calves, specifically in restoring gut barrier function and immunity when diarrhea incidence is high during the initial weeks of life (Urie et al. 2018a); however, research at the calf level to determine the potential direct effects bovine OS may have on maintaining a homeostatic gut environment during health or production challenges, as well as during normal physiological conditions, is required.

Despite recent research revealing reasons for high concentrations of bovine OS in colostrum, there is a lack of research characterizing the synthesis of OS in the bovine mammary gland. In the human mammary gland, the process of OS synthesis begins with the formation of lactose, which is then elongated to lacto-N-biose or $\mathrm{N}$-acetyllactosamine (as reviewed by Smilowitz et al. 2014). Sialic acid is synthesized in the cytosol and imported to the nucleus and converted to CMP-Neu5Ac, followed by translocation to the Golgi apparatus for modification and conjugation to glycoconjugates by sialyltransferases (Fig. 1A; Huizing 2005). A total of 92 glycosylation-related genes, with 29 genes identified as important for the synthesis and metabolism of sialylated OS, have been characterized in milk somatic cells of Holstein and Jersey cows at 15 and 250 days in milk 
(Wickramasinghe et al. 2011); yet, the expression patterns of these genes during early lactation, as well as the specific enzymes and cofactors that catalyze the formation of the major OS in bovine colostrum, have not been elucidated.

The concentrations and number of os secreted by individual cows is highly variable. The concentrations of the major OS in colostrum, 3'SL, can range from 147.0 to $1149.8 \mu \mathrm{g} \cdot \mathrm{mL}^{-1}$ (Fischer-Tlustos et al. 2020a), and the total number of OS secreted in colostrum can vary from 14 to 32 even when breed, parity, nutrition, and season of calving are controlled for (Barile et al. 2010). In humans, one of the most well-known sources of variation in OS composition is genetic variability (Ninonuevo et al. 2006), specifically Lewis blood group and secretor status (Smilowitz et al. 2014). To our knowledge, no studies have been conducted regarding the effect of genetic variability on bovine OS composition. Conversely, studies often focus on management, environmental or dam factors that may influence OS concentrations. Research has shown parity can influence colostral os yield, with multiparous cows having greater yields than primiparous cows (Fischer-Tlustos et al. 2020a). To the authors' knowledge, only one study has examined the effect of breed on colostral os concentrations, demonstrating that Jersey colostrum contains higher levels of disialyllactose and 3'SL and lower levels of 6'sialyllactose than Friesian colostrum (McJarrow and van AmelsfortSchoonbeek 2004). Unfortunately, this study only analyzed the four primary acidic OS in colostrum, whereas it has been clearly demonstrated that breed (Robinson et al. 2019) and production type (i.e., beef vs. dairy; Sischo et al. 2016) can have significant effects on the abundance of up to 13 different OS structures during both early and mid-lactation. The differences in diet composition between production type may partially explain the observed differences in OS abundance (Sischo et al. 2016); however, recent research found no differences in colostral os composition in cows $(n=3$ per treatment) fed prepartum diets consisting of either exclusively grass or corn and alfalfa silage, earlage, and grain (Vicaretti et al. 2018). Further studies investigating the effects of prepartum diet composition on OS concentrations using large sample sizes, while controlling for breed and parity, are required.

It is possible that prepartum health status of the dam may also affect colostral os concentrations. In an effort to elucidate prepartum serum biomarkers that precede the development of clinical mastitis during lactation, Zandkarimi et al. (2018) found that cows that developed clinical mastitis post-calving displayed a $1440 \%$-fold increase in serum $3^{\prime}$ SL at $21 \mathrm{~d}$ prior to calving compared with healthy cows. At calving, a 125\%-fold change was still observed; however, authors did not measure 3'SL concentrations in colostrum to determine if high serum 3'SL was correlated with high levels of colostral 3'SL (Zandkarimi et al. 2018). Research has shown that 3'SL and 6' sialyllactosamine in colostrum are moderately correlated with colostral somatic cell counts (FischerTlustos et al. 2020a); however, research pertaining directly to potential roles of OS in the mammary immune response, and consequently their concentrations in colostrum, is required.

\section{Fatty acids}

The colostral and transition milk (TM) FA profiles are distinct from that of WM (Contarini et al. 2014; O'Callaghan et al. 2020). Concentrations of long-chain saturated FA (LCSFA) are increased in colostrum and TM, whereas short-chain saturated FA (SCSFA) concentrations are decreased compared with WM, and mediumchain saturated FA (SFA) concentrations do not dramatically change (Contarini et al. 2014; O'Callaghan et al. 2020). The major FA biosynthesis pathways within the mammary gland (preformed and de novo pathways; Fig. 1A) are presumably conserved in Lactogenesis I and II; however, the activities of the preformed and de novo pathways likely differ between those stages due to relative differences in endocrine stimulation and substrate supply during pregnancy and lactation, consequently altering the FA composition of colostrum relative to WM. Peripartum negative energy balance might elevate colostral LCSFA by causing the release of long-chain FA from adipose tissue for incorporation into colostral fat (Belyea and Adams 1990; McGrath et al. 2016). By extent, McGrath et al. (2016) suggested in their review that increased long-chain FA might reduce colostral SCSFA concentrations through inhibition of de novo SCSFA synthesis within the mammary gland (Bauman and Davis 1974). Contarini et al. (2014) observed lower SCSFA concentrations concurrent with greater LCSFA concentrations in colostrum. However, over-supplying metabolizable energy (ME) to dairy cattle relative to cows consuming $\mathrm{ME}$ at requirements did not confirm that preformed and de novo FA are present in opposing concentrations in colostrum (Mann et al. 2016). To our knowledge, it is unknown whether a severe prepartum ME restriction would increase preformed FA to an extent that could inhibit de novo FA synthesis in colostrum.

There are numerous FA species that have been identified in colostrum and a detailed description of the concentrations and patterns of change of all FA within colostrum is beyond the scope of this review. Thus, we focus on FA that have well-established importance during development. Colostral and TM long-chain polyunsaturated FA (such as the elevated $\omega-3$ and -6 FA, Table 1; Contarini et al. 2014; O'Callaghan et al. 2020) are particularly important for neonatal calves because placental transport of long-chain FA is limited in ruminant species (Bell and Ehrhardt 2002). $\omega$-Fatty acids are essential to neonatal development (reviewed by Moallem 2018); yet, evidence suggests that neonates may be marginally deficient in $\alpha$-linolenic (ALA, C18:3 $\omega$-3) and linoleic (LA, C18:2 $\omega-6$ ) acid (Payne 1978; Noble et al. 1985; Garcia et al. 
2014). The LA concentration is increased in colostrum compared with WM (Leiber et al. 2011). By contrast, ALA concentrations remained relatively stable after calving and were only reduced (by $31 \%-35 \%$ ) at the second milking when compared with colostrum and WM (Hare et al. 2019a). Within the $\omega-3$ and -6 biosynthetic pathways, ALA is the precursor to the essential $\omega$-FA, eicosapentaenoic (C20:5 $\omega$-3) and docosahexaenoic

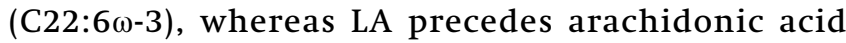

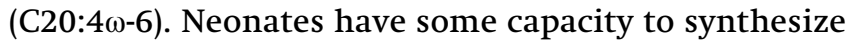
arachidonic acid from LA (Noble et al. 1978), but their ability to convert ALA to eicosapentaenoic and docosahexaenoic acid is less clear. Coincidentally, arachidonic, eicosapentaenoic, and docosahexaenoic acid concentrations in colostrum $(0.52 \%, 0.11 \%$, and $0.014 \%$ FA, respectively) are all elevated (Contarini et al. 2014; Hare et al. 2019a) and drastically decrease in WM by $67 \%-72 \%$ of their initial concentration in colostrum (Hare et al. 2019a).

Colostral fat is readily absorbed by the small intestine in neonatal calves (Fig. 1B) in a manner similar to that of mature ruminants (Gooden et al. 1971). The postabsorptive effect of specific colostral FA on neonatal calf development is generally understudied and mainly focused on $\omega$-FA (Garcia et al. 2014, 2016; Coleman et al. 2018; Opgenorth et al. 2020a, 2020b; 2020c; Ricks et al. 2020). Several studies have evaluated indirectly supplementing $\omega$-FA to neonatal calves by feeding more $\omega$-FA prepartum to increase colostral concentrations (Garcia et al. 2014; Jolazadeh et al. 2019b; Ricks et al. 2020). Although these studies highlighted that indirect $\omega$-FA supplementation can affect IgG absorption by neonatal calves and possibly elicit developmental programming responses (Garcia et al. 2016; Marques et al. 2017), it is difficult to discern whether these effects are due to the colostral FA content, placental transport (i.e., in utero programming; Salehi and Ambrose 2017), or both. Directly supplementing $\omega$-FA in colostrum may be a more efficacious strategy to ensure that neonatal $\omega$-FA intake is adequate; however, we are only aware of one group that has evaluated supplementing $\omega-3$ FA directly in colostrum to neonatal calves (Opgenorth et al. 2020a, $2020 b, 2020 c$ ). Adding fish and flaxseed oil and $\alpha$-tocopherol to colostrum did not alter indicators of health or growth performance; but, supplementation increased plasma $\omega-3$ FA concentrations, decreased plasma $\alpha$-tocopherol and oxidant status index during week 1 postnatal, and tended to decrease reactive oxygen and nitrogen species (Opgenorth et al. 2020b). When $\omega$-FA are supplemented in WM or milk replacer, calves are often healthier and grow at faster rates (Karcher et al. 2014; Garcia et al. 2015, 2016; Worden et al. 2018; McDonnell et al. 2019; Śpitalniak-Bajerska et al. 2020). Similar responses are observed when $\omega$-FA are supplemented in starter postweaning (Kadkhoday et al. 2017). However, Opgenorth et al. (2020a, 2020b, 2020c) did not observe differences in growth rate due to fish and flaxseed oil and (or) $\alpha$-tocopherol supplementation in colostrum; although, improvements and tendencies for improvements in health scores were found in some studies (Opgenorth et al. 2020b, 2020c).

Butyrate $(\mathrm{C} 4: 0)$ has also received attention in preweaned calves as it enhances gastrointestinal, enzymatic, and pancreatic development when supplemented in liquid feed, consequently improving growth performance and health parameters (reviewed by Górka et al. 2018). Though little is known about the effect of colostral butyrate on neonatal development, preliminary evidence suggests that it may adversely affect dairy calf immunity (Hiltz and Laarman 2019). By supplementing butyrate $(2.5 \% w / v)$ in CR, serum IgG concentrations were reduced from 21.1 to $14.0 \mathrm{~g} \cdot \mathrm{L}^{-1}$ at $24 \mathrm{~h}$ and remained low for the remainder of the study (Hiltz and Laarman 2019). Baumwart et al. (1977) observed that feeding potassium-isobutyrate in colostrum at $1 \mathrm{~h}$ postpartum decreased neonatal absorption and serum concentrations of $\gamma$-globulin, IgG, and IgM. It has been speculated that butyrate might accelerate intestinal development in neonates by causing premature loss of giant-sized vacuoles in fetal-type enterocytes that uptake and translocate macromolecules into the periphery (reviewed in Skrzypek et al. 2018); thereby, diminishing absorption of colostral IgG. Although this mechanism is yet to be confirmed, it is interesting to consider respective to the fact that the abundance of colostral butyrate is low and only increases in TM on day 3 post-calving (O'Callaghan et al. 2020). Theoretically, the low butyrate concentrations in colostrum and the initial TM might help to prolong the period in which the neonatal gut is permeable to macromolecules. Based on these results, maternal factors that increase colostral butyrate should be avoided, and butyrate should not be supplemented to newborn calves during the first $1-2 \mathrm{~d}$ postnatal.

Season, dry period length, parity, and concentrate or fibre consumption all alter colostrum fat and FA content (Coroian et al. 2013; Dunn et al. 2017; O'Callaghan et al. 2020). Prepartum ME and metabolizable protein intake also influence colostrum fat concentrations (Mann et al. 2016; Hare et al. 2019b), possibly by maternal plasma insulin modulating the release of nonesterified FA from adipose tissue (Mann et al. 2016; Zinicola and Bicalho 2019). Prepartum ME intake can also alter the colostral FA profile (Mann et al. 2016). Similarly, multiple studies have concluded that prepartum fat intake and source can be used to influence the FA present in colostrum (Leiber et al. 2011; Garcia et al. 2014; Salehi et al. 2016; Marques et al. 2017; Coleman et al. 2018; Jolazadeh et al. 2019a; Ricks et al. 2020). As FA participate in a wide variety of physiological functions (De Carvalho and Caramujo 2018; Moallem 2018), further consideration should be given to how maternal prepartum factors influence colostrum fat and FA content to understand the downstream influence on neonatal calf development. 


\section{Insulin-relaxin superfamily}

Colostrum contains high concentrations of numerous bioactive hormones [reviewed previously by Blum and Hammon (2000) and McGrath et al. (2016)] that can be broadly grouped as either steroidic or peptidic hormones (Jouan et al. 2006). Colostral hormones that are commonly discussed are growth hormone, epidermal growth factor, transforming growth factor- $\beta$ (Gauthier et al. 2006; Jouan et al. 2006; Ontsouka et al. 2016), and several peptide hormones (insulin-like growth factors) clustered within the insulin-relaxin superfamily. This family of peptides have been previously reviewed (Blum and Hammon 2000; Blum and Baumrucker 2002; Blum and Baumrucker 2008), and herein, we expand the discussion to include the remaining members of the ancestral insulin-relaxin superfamily. These peptides are grouped into subfamilies: (1) insulin (INS), (2) insulinlike growth factors (IGF), (3) the insulin-like peptides and polypeptides (INSL), and (4) the relaxins (RLN). Although the superfamily is structurally conserved, they may differ in expression and physiological roles between species (Hoffman and Opazo 2011).

Insulin, IGF-I, and IGF-II are all bioactive, and their concentrations are elevated in bovine colostrum relative to WM (reviewed in Blum and Hammon 2000). Though RLN has also been identified in porcine colostrum and is documented to impact neonatal reproductive development (Frankshun et al. 2011; Bagnell and Bartol 2019), it is not anticipated to be present in bovine colostrum as ruminant species lack the ability to produce RLN due to evolutionary gene erosion (Roche et al. 1993; Hoffman and Opazo 2011; Malone et al. 2017). Bovine colostrum also contains elevated concentrations of IGF-binding proteins-2, -3, -4, and -5 (Sejrsen et al. 2001; Sparks et al. 2003) that may modulate the activity of colostral IGF-I or possibly have their own direct action on mammary or intestinal development (reviewed by Blum and Baumrucker 2002). To our knowledge, INSL have not been identified in bovine colostrum; though, it is plausible that they could be present as INSL3, INSL5, and INSL6 (but not INSL4) are putatively functional in the bovine genome (Hoffman and Opazo 2011; Malone et al. 2017), and INSL3 is expressed in ovarian follicles (Anand-Ivell et al. 2011; Satchell et al. 2013; Dai et al. $2017 a, 2017 b)$. Interestingly, female ruminants produce exceptionally high concentrations of ovarian INSL3 relative to other species (Bathgate et al. 1996, 1999) and, as INSL3 acts on the same G-protein coupled receptors as RLN (RXFP1 and RFXP2; Bathgate et al. 2013; Dai et al. $2017 b$ ), it has been proposed that INSL3 is a compensatory homologue for the lack of endogenous RLN production (Bathgate et al. 1996; Anand-Ivell et al. 2011). Should INSL3 be confirmed in bovine colostrum, it may speculatively influence neonatal reproductive development similar to RLN in porcine colostrum, possibly more so in male than female calves (Anand-Ivell et al. 2011).
Insulin-like growth factors-I and -II target the GIT of calves, and the greatest binding capacity for IGF is in the ileum and colon (IGF-IR) or the duodenum (IGF-IIR; Georgiev et al. 2003; Georgieva et al. 2003). Colostral IGF-I concentrations are twice that of IGF-II (Blum and Hammon 2000) and are approximately 2 and $3.4 \times$ greater than neonatal (Hadorn et al. 1997; Schäff et al. 2016) and antepartum maternal (Piechotta et al. 2015) serum IGF-I, respectively. Lacteal IGF-I and -II must be sourced from maternal circulation (Malven et al. 1987; Prosser et al. 1991) given that there is limited evidence that either hormone is synthesized by the mammary gland (Campbell et al. 1991), indicating that movement of IGF-I and -II into mammary secretions must occur transcellularly by active transport to establish concentrations in colostrum greater than in blood (Fig. 1A); although, it is also possible that some movement of IGF-I and -II into colostrum could occur paracellularly via molecular sieving (Fig. 1A) by "leaky" tight junctions (reviewed by Weber 2012) during Lactogenesis I.

The greater IGF-I concentration in colostrum coupled with its role in regulating postnatal growth (whereas IGF-II action predominates during fetal growth; reviewed by Breier et al. 2000) could suggest that colostral IGF-I likely has a greater role in neonatal calf development than colostral IGF-II. However, the extent to which IGF-I can solely influence postnatal intestinal development is unclear, as results are contradictory (discussed by Blum and Baumrucker 2002), but it is accepted that colostral bioactive growth factors, including IGF-I, synergistically promote intestinal maturation (Fig. 1B; Roffler et al. 2003; Pyo et al. 2020). Insulin-like growth factor-I and -II are additionally not believed to permeate the intestine (Blum and Baumrucker 2002; Hammon et al. 2020), as recombinant human IGF-I was absorbed in negligible quantities from isolated jejunal loops in 1-d-old feed-deprived calves (Vacher et al. 1995); however, there is some evidence to the contrary (Skaar et al. 1994; Sparks et al. 2003). Colostral IGF-I absorption by neonatal piglets is also controversial ( $\mathrm{Xu}$ and Wang 1996; Burrin 1997; Donovan et al.1997); yet, orally supplemented IGF-I in colostrum or milk replacer supported cervical and uterine development in neonatal gilts (Camp et al. 2018; George et al. 2018). These recent data demonstrate that colostral IGF-I can be absorbed by neonates whilst the intestine is hyperpermeable and suggests that its absorption by calves may need to be reevaluated within the first hours of life, as opposed to $1 \mathrm{~d}$ of life (Vacher et al. 1995). Similar to its movement within the mammary gland, absorption of IGF-I could occur via active transport once IGF-I binds to its receptor in the intestinal tract or, to some extent, IGF-I could permeate the intestinal epithelial barrier passively prior to intestinal maturation (Fig. 1B). Furthermore, hepatic GH binding is low in the neonatal liver (Gluckman et al. 1983; Badinga et al. 1987; Breier et al. 1988), leading to 
inadequate stimulation of hepatic IGF-I and is partially responsible for the typically low serum IGF-I concentrations of neonatal calves (reviewed by Breier and Gluckman 1991). Therefore, absorption of colostral IGF-I could be a compensatory mechanism to bypass the $\mathrm{GH}$ arm of the somatotropic growth axis and promote growth and development of the calf during the immediate postnatal period.

Similar to IGF-I, it is probable that colostral INS also plays a major role in neonatal development. Substantial quantities of INS are sequestered by the mammary gland prior to calving (Malven et al. 1987), such that colostral INS concentrations are between 41 and $76 \times$ greater than antepartum maternal (Malven et al. 1987; Hare et al. $2019 b$; K. Hare et al. unpublished data) and neonatal plasma INS concentrations (Rauprich et al. 2000; Hammon et al. 2000). As with IGF-I, it is probable that transfer of INS into mammary secretions predominantly occurs by active transport against its concentration gradient (Malven et al. 1987; Whitmore et al. 2012) after binding to its receptor (Fig. 1A); though, it is again possible that some translocation could occur by molecular sieving through "leaky" tight junctions (Fig. 1A) during Lactogenesis I. In the neonatal intestine, insulin receptor mRNA is most highly expressed in the jejunum and colon of full-term calves prior to colostrum feeding but binding capacity is equivalent through the small intestine and colon (Georgiev et al. 2003). Colostral INS likely enhances intestinal growth and maturation through mitogenic signaling and other undefined mechanisms after binding its intestinal INS receptor (Fig. 1B). Oral INS delivery promotes gastrointestinal cell proliferation and enzymatic activity in rodents (Menard et al. 1981; Simon et al. 1982; Arsenault and Menard 1984; Buts et al. 1990; Albert et al. 1994) and increases small intestinal mass and disaccharidase activity in suckling piglets (Shulman 1990). Additionally, INS and GH receptor mRNA expression was greater in the ileum of neonatal piglets supplemented with INS (Huo et al. 2006). In addition, insulin treatment caused jejunal leucine aminopeptidase activity and $3 \mathrm{~d}$ BW to increase (Huo et al. 2006). In 30-h-old neonatal calves, rumen mass and abomasal wet digesta weight were reduced after they were fed colostrum containing INS concentrations 5 and $10 \times$ greater than that of the control (control: $16.8 \mu \mathrm{g}$ INS $\cdot \mathrm{L}^{-1}$; K. Hare et al. unpublished data). Colostral INS supplementation also increased duodenal tissue density $\left(\mathrm{g}\right.$ tissue $\cdot \mathrm{cm}^{-1}$ length) and tended to increase wet digesta weight in the colon (K. Hare et al. unpublished data). Speculatively, this preliminary data indicates that supplementary colostral INS may have increased gut motility and accelerated digesta passage through the neonatal calf intestine, possibly by insulin-induced hypoglycemia (Fellows et al. 1987; Schvarcz et al. 1993; Schvarcz et al. 1995; Russo et al. 2005).

Gastrointestinal INS absorption has been demonstrated in many species, including neonatal and mature rats (Mosinger et al. 1959; Kidron et al. 1982; Morishita et al. 1993; Asada et al.1995), neonatal pigs (Asplund et al. 1962; Shen and Xu 2000), and dogs (Chernikov et al. 1972). Speculatively, absorption may occur via binding to INS receptors within the intestinal tract, or possibly by passive diffusion across the "open" neonatal gut (Fig. 1B). In neonatal calves, consuming supraphysiological concentrations of INS shortly after birth causes plasma glucose to decrease as early as $1 \mathrm{~h}$ after treatment (Kirovski et al. 2008), sometimes inducing a hypoglycemic coma (Pierce et al. 1964). The absorption of colostral INS in neonatal calves is contended (Hammon et al. 2013; Hammon et al. 2020), as a study that delayed feeding and did not control macronutrient intake between treatments did not observe an appreciable rise in immunoreactive insulin when insulin was supplemented in colostrum (Grütter and Blum 1991). It is possible that first-pass hepatic INS clearance might mask intestinal absorption unless large concentrations of colostral INS are consumed. Intestinal absorption of whole and biologically active INS likely compensates for the underdeveloped pancreatic response (Grütter and Blum 1991), promoting the flux of nutrients into peripheral tissues, storage of hepatic glycogen, and supporting the rapid neonatal metabolism and growth (Vermorel et al. 1983; Sadri et al. 2017).

\section{Additional bioactive components for consideration}

The bioactive factors in colostrum are not limited to the aforementioned molecules and compounds; a plethora of additional colostral factors have the potential to improve calf immune and developmental function. For instance, microRNAs (miRNA), specifically those related to immune regulation, are present at higher concentrations in colostrum compared with milk (Izumi et al. 2012; Zhou et al. 2012; Sun et al. 2013; Table 1). These miRNA are highly resistant to RNase and acidic conditions (Izumi et al. 2012) and neonatal rats fed colostrum have a higher number of immune-related miRNA in serum compared with those fed mature milk (Izumi et al. 2014). This suggests a mechanism for miRNA absorption by the neonatal intestine, and their potential role in immune regulation both systemically and locally in the mucosal immune system of the GIT (Liang et al. 2015). Similarly, nucleotide concentrations are $17 \times$ greater in bovine colostrum compared with WM (Gill et al. 2011; Table 1), with uridine $5^{\prime}$ monophosphate (5'UMP) being the predominant nucleotide (Gil and Sanchez-Medina 1981). Mashiko et al. (2009) demonstrated that calves 4-10 d of age supplemented with 5'UMP in milk replacer had improved immune function, specifically increased interferon- $\gamma$ concentrations by peripheral blood mononuclear cells and greater IgA concentrations in the ileal mucosa, compared with control calves. Due to the high concentrations of $5^{\prime} \mathrm{UMP}$ in bovine colostrum, it can be hypothesized that its effect on immune function during the first day of life, as opposed to days 4-10, may be more 
pronounced; however, the effects of dietary 5'UMP and other nucleotides in colostrum on the immune response of neonatal calves has not been investigated.

Recent advancements in high-throughput laboratory techniques have allowed the dairy research community to thoroughly evaluate the bovine colostrum and milk proteome. Researchers have identified many unique classes of proteins that are upregulated or exclusively detected in dairy colostrum compared with WM, including osteopontin, antibody and complement components, antimicrobial proteins, anti-proteolytic proteins, and multiple growth and differentiation factors (Le et al. 2011; Nissen et al. 2017; Fahey et al. 2020). Additionally, the colostrum proteome in beef calves has been of research interest. The whole colostrum proteomes and $2 \mathrm{~d}$ calf serum samples from beef cows fed at $100 \%$ or $133 \%$ of MP requirements for approximately $8 \mathrm{wk}$ prior to calving (Hare et al. 2019b) revealed that a total of 213 distinct detectable proteins were found in whole colostrum, 11 of which increased and 16 of which decreased $>2$ $\log _{2}$ fold between maternal diets. The serum proteome of 2-d-old calves identified 179 proteins pre-and postcolostrum consumption. Of these, 28 were increased, and 19 were decreased $>2 \log _{2}$ fold between calves. A number of these differentially detected proteins in calf serum tended towards pathways shifts in decreasing innate and increasing adaptive immune response factors from colostrum of high MP fed dams (Radford et al. 2018). There has also been increasing interest in the proteome specific to the milk fat globule membrane (MFGM). Although the MFGM constitutes only $1 \%-4 \%$ of milk protein in dairy cows (Yang et al. 2015), it contains a diverse profile of hundreds of proteins (Reinhardt and Lippolis 2008; Ji et al. 2017) that have been implicated in positively influencing the host gut microbiome and the immune system (Rasmussen 2009; Bhinder et al. 2017). Honan et al. (2020) found that $78 \%$ of proteins affected by days in milk had a higher abundance in colostrum compared with day 7 milk, including proteins involved in pathogen detection and supporting host immunity.

From the abundance of research reviewed previously (Pakkanen and Aalto 1997; Blum and Hammon 2000; McGrath et al. 2016) and described herein, it is clear that colostrum has an integral role in not only ensuring TPI but also in stimulating the metabolism, development of the GIT, and mucosal and systemic immune system of the neonatal calf. The recent characterization of the multitude of colostral bioactive factors that positively influence neonatal calf health and development highlights the potential need for redefining the term "colostrum quality" to encompass more than IgG. However, future research at the calf level is required to evaluate the specific mechanisms by which certain bioactive compounds influence the neonatal calf. Elucidating these mechanisms will allow the dairy research community to rank colostral components by level of importance to determine the specific compounds that fit within the scope of the modern definition of "colostrum quality". It may be possible to utilize colostrum IgG concentrations as a "indicator" of colostrum containing adequate or high concentrations of the aforementioned bioactive compounds, given its strong positive correlations with the major OS in bovine colostrum, 3'sialyllactose (FischerTlustos et al. 2020a). It may be possible that IgG can reliably indicate high concentrations of the plethora of additional bioactive compounds in bovine colostrum; yet further work characterizing the correlations between IgG and specific bioactive compounds, as well as the concentrations at which these bioactive compounds are of physiological relevance to the neonatal calf, is required. As colostrum IgG concentrations can be accurately and easily measured on farm using a Brix refractometer (Deelen et al. 2014). determining these associations would provide the dairy industry with an efficient cow-side test to ensure that colostrum not only meets the gold-standard for providing passive immunity but also the bioactive compounds required for proper development and health.

\section{Summary and Conclusions}

In summary, maximizing colostrum quality and enhancing colostrum feeding practices will undoubtedly translate into improved health and well being of calves and improved profits for dairy and beef producers. Although the research community is conducting more colostrum research now than ever before, surveys around the world and in Canada still report alarming incidences of poor colostrum feeding strategies and high morbidity and mortality levels. These statistics highlight a great opportunity to improve the basic concepts of colostrum feeding (quality, quantity, and quickness) and newer concepts like extended colostrum feeding. Colostrogenesis is a key research area that has been neglected in bovine research and requires more attention. Future studies investigating nutritional and management strategies for dry cows will enable us to maximize the synthesis of colostrum bioactive components that are beneficial for calf developmental programming and lifetime performance. Furthering our understanding and definition of colostrogenesis and colostrum quality - as both are currently focused solely on IgG - will also be essential to move bovine colostrum research forward. Characterizing not only IgG, but also the hundreds of bioactive compounds in colostrum, as well as elucidating the mechanisms that control their synthesis, would be invaluable to our industry. It is also critical to understand the degree of absorption and functionality of each bioactive component within colostrum and how it relates to health and long-term productivity. Once we understand how differing concentrations of these bioactive components impact calf performance, our definition of colostrum, and colostrogenesis, will inevitably evolve. 


\section{References}

Albert, V., Barkla, D., and Young, G. 1994. Serum-free organ culture of the suckling rate jejunum. Effect of regulatory hormones. In Vitro Cell. Dev. Biol. Anim. 30A: 443-449. doi:10.1007/bf02631312. PMID:7952513.

Anand-Ivell, R.S., Hiendleder, C., Viñoles, G.B., Martin, C., Fitzsimmons, C., Eurich, A., et al. 2011. INSL3 in the ruminant: a powerful indicator of gender- and genetic-specific feto-maternal dialogue. PLoS ONE, 6: e19821. doi:10.1371/ journal.pone.0019821. PMID:21603619.

Armengol, R., and Fraile, L. 2016. Colostrum and milk pasteurization improve health status and decrease mortality in neonatal calves receiving appropriate colostrum ingestion. J. Dairy Sci. 99: 4718-4725. doi:10.3168/jds.2015-10728. PMID:26995131.

Arsenault, P., and Menard, D. 1984. Insulin influences the maturation and proliferation of suckling mouse intestinal mucosa in serum free organ culture. Biol. Neonate, 46: 229-236. doi:10.1159/000242070. PMID:6391567.

Arthur, G.H. 1996. The development of the conceptus. Pages 51-109 in G.H. Arthur, D.E. Nokes, H. Pearson, et al., eds. Pregnancy and parturition in veterinary reproduction and obstetrics, 7th ed. W.B. Saunders, Philidelphia, PA, USA.

Asada, H., Douen, T., Waki, M., Adachi, S., Fujita, T., Yamamoto, A., and Muranishi, S. 1995. Absorption characteristics of chemically modified-insulin derivatives with various fatty acids in the small and large intestine. J. Pharm. Sci. 84: 682-687. doi:10.1002/jps.2600840604. PMID:7562404.

Asplund, J.M., Grummer, R.H., and Phillips, P.H. 1962. Absorption of colostral gamma-globulins and insulin by the newborn pig. J. Anim. Sci. 21: 412-413. doi:10.2527/jas1962. 213412x.

Badinga, L., Collierr, R.J., Thatcher, W.W., Quinttana, S.J., and Bazer, F.W. 1987. Covalent coupling of bovine growth hormone to its receptor in bovine liver membranes. Mol. Cell. Endocrinol. 52: 85-89. doi:10.1016/0303-7207(87)90100-6. PMID:3622922.

Bagnell, C.A., and Bartol, F.F. 2019. Relaxin and the 'Milky Way': the lactocrine hypothesis and maternal programming of development. Mol. Cell. Endocrinol. 487: 18-23. doi:10.1016/ j.mce.2019.01.003. PMID:30629990.

Barile, D., Marotta, M., Chu, C., Mehra, R., Grimm, R., Lebrilla, C.B., and German, J.B. 2010. Neutral and acidic oligosaccharides in Holstein-Friesian colostrum during the first 3 days of lactation measured by high performance liquid chromatography on a microfluidic chip and time-of-flight mass spectrometry. J. Dairy Sci. 93(9): 3940-3949. doi:10.3168/jds.20103156. PMID:20723667.

Barrington, G.M., McFadden, T.B., Huyler, M.T., and Besser, T.E. 2001. Regulation of colostrogenesis in cattle. Livest. Prod. Sci. 70: 95-104. doi:10.1016/S0301-6226(01)00201-9.

Bathgate, R., Balvers, M., Hunt, N., and Ivell, R. 1996. Relaxinlike factor gene is highly expressed in the bovine ovary of the cycle and pregnancy: sequence and messenger ribonucleic acid analysis. Biol. Reprod. 55: 1452-1457. doi:10.1095/ biolreprod55.6.1452. PMID:8949906.

Bathgate, R., Moniac, N., Bartlick, B., Schumacher, M., Fields, M., and Ivell, R. 1999. Expression and regulation of relaxin-like factor gene transcripts in the bovine ovary: differentiationdependent expression in theca cells cultures. Biol. Reprod. 61: 1090-1098. doi:10.1095/biolreprod61.4.1090. PMID:10491648.

Bathgate, R.A.D., Halls, M.L., van der Westhuizen, E.T., Callander, G.E., Kocan, M., and Summers, R.J. 2013. Relaxin family peptides and their receptors. Physiol. Rev. 93: 405-480. doi:10.1152/physrev.00001.2012. PMID:23303914.
Bauman, D.E., and Davis, C.L. 1974. Biosynthesis of milk fat. In B.L. Larson and V.R. Smith, eds. Lactation-a comprehensive treatise. Academic Press, New York, NY, USA. pp. 31-75

Bauman, D.E., and Griinari, J.M. 2003. Nutritional regulation of milk fat synthesis. Annu. Rev. Nutr. 23: 203-226. doi:10.1146/ annurev.nutr.23.011702.073408. PMID:12626693.

Baumrucker, C.R., and Bruckmaier, R.M. 2014. Colostrogenesis: IgG1 transcytosis mechanisms. J. Mammary Gland Biol. Neoplasia, 19: 103-117. doi:10.1007/s10911-013-9313-5. PMID:24474529.

Baumrucker, C.R., Burkett, A.M., Magliaro-Macrina, A.L., and Dechow, C.D. 2010. Colostrogenesis: mass transfer of immunoglobulin G1 into colostrum. J. Dairy Sci. 93: 3031-3038. doi:10.3168/jds.2009-2963. PMID:20630219.

Baumwart, A.L., Bush, L.J., and Mungle, M. 1977. Effect of potassium isobutyrate on absorption of immunoglobulins from colostrum by calves. J. Dairy Sci. 60: 759-762. doi:10.3168/ jds.S0022-0302(77)83931-3. PMID:68043.

Bell, A.W., and Ehrhardt, R.A. 2002. Regulation of placental nutrient transport and implications for fetal growth. Nutr. Res. Rev. 15: 211-230. doi:10.1079/NRR202239. PMID:19087405.

Belyea, R.L., and Adams, M.W. 1990. Energy and nitrogen utilization of high versus low producing dairy cows. J. Dairy Sci. 73: 1023-1030. doi:10.3168/jds.s0022-0302(90)78761-9. PMID:2345194.

Besser, T.E., and Gay, C.C. 1994. The importance of colostrum to the health of the neonatal calf. Vet. Clin. North Am. Food Anim. Prac. 10: 107-117. doi:10.1016/s0749-0720(15)30591-0. PMID:8199914.

Bhinder, G., Allaire, J.M., Garcia, C., Lau, J.T., Chan, J.M., Ryz, N.R., et al. 2017. Milk fat globule membrane supplementation in formula modulates the neonatal gut microbiome and normalizes intestinal development. Sci. Rep. 7: 45274. doi:10.1038/srep45274. PMID:28349941.

Blum, J.W., and Baumrucker, C.R. 2002. Colostral and milk insulin-like growth factors and related substances: mammary gland and neonatal (intestinal and systemic targets). Domest. Anim. Endocrinol. 23: 101-110. doi:10.1016/S07397240(02)00149-2. PMID:12142230.

Blum, J.W., and Baumrucker, C.R. 2008. Insulin-like growth factors (IGFs), IGF binding proteins, and other endocrine factors in milk: role in the newborn. Pages $397-422$ in Z. Bösze, ed. Bioactive components of milk. Springer. doi:10.1007/ 978-0-387-74087-4_16.

Blum, J.W., and Hammon, H. 2000. Colostrum effects on the gastrointestinal tract, and on nutritional, endocrine and metabolic parameters in neonatal calves. Livest. Prod. Sci. 66: 151-159. doi:10.1016/s0301-6226(00)00222-0

Bonk, S., Nadalin, A., Heuwieser, W., and Veira, D. 2016. Lying behavior and IgG-levels of newborn calves after feeding colostrum via tube and nipple bottle feeding. J. Dairy Res. 83: 298-304. doi:10.1017/s0022029916000285. PMID:27600963.

Boudry, G., Hamilton, M.K., Chichlowski, M., Wickramasinghe, S., Barile, D., Kalanetra, K.M., et al. 2017. Bovine milk oligosaccharides decrease gut permeability and improve inflammation and microbial dysbiosis in diet-induced obese mice. J. Dairy Sci. 100: 2471-2481. doi:10.3168/jds.2016-11890. PMID:28131576.

Brandon, M.R., Watson, D.L., and Lascelles, A.K. 1971. The mechanism of transfer of immunoglobulins into mammary secretions of cows. Aust. J. Exp. Biol. Med. Sci. 49: 613. doi:10.1038/icb.1971.67.

Breier, B.H., and Gluckman, P.D. 1991. The regulation of postnatal growth: nutritional influences on endocrine pathways and function of the somatotrophic axis. Livest. Prod. Sci. 27: 77-94. doi:10.1016/0301-6226(91)90047-T.

Breier, B.H., Oliver, M.H., and Gallaher, B.W. 2000. Regulation of growth and metabolism during postnatal development. 
Pages 187-204 in P.B. Cronjé, ed. Ruminant physiology: digestion, metabolism, growth, and reproduction. CABI Publishing, New York, NY, USA.

Breier, B.H., Gluckman, P.D., and Bass, J.J. 1988. Plasma concentrations of insulin-like growth factor-I and insulin in the infant calf: ontogeny and influence of altered nutrition. J. Endocrinol. 119: 43-50. doi:10.1677/joe.0.1190043. PMID:3057103.

Buczinski, S., Gicquel, E., Fecteau, G., Takwoingi, Y., Chigerwe, M., and Vandeweerd, J. 2018. Systematic review and metaanalysis of diagnostic accuracy of serum refractometry and brix refractometry for the diagnosis of inadequate transfer of passive immunity in calves. J. Vet. Intern. Med. 32: 474-483. doi:10.1111/jvim.14893. PMID:29210105.

Bühler, C., Hammon, H., Rossi, G.L., and Blum, J.W. 1998. Small intestinal morphology in eight-day-old calves fed colostrum for different durations or only in milk replacer and treated with long-R3-insulin-like growth factor I and growth hormone. J. Anim. Sci. 76: 758-765. doi:10.2527/1998.763758x. PMID:9535335.

Burrin, D.G. 1997. Is milk-borne insulin-like growth factor-1 essential for neonatal development? J. Nutr. 127: 975S-979S. doi:10.1093/jn/127.5.975S. PMID:9164277.

Bush, L.J., and Staley, T.E. 1980. Absorption of colostral immunoglobulins in newborn calves. J. Dairy Sci. 63: 672-680. doi:10.3168/jds.S0022-0302(80)82989-4. PMID:6991559.

Butler, J.E. 1983. Bovine immunoglobulins: an augmented review. Vet. Immunol. Immunopathol. 4: 43-152. doi:10.1016/ 0165-2427(83)90056-9. PMID:6223434.

Butler, J.E. 1994. Passive immunity and immunoglobulin diversity. In Indigenous antimicrobial agents of milk. Recent developments, 31 Aug.-1 Sept. 1993. FIL-IDF. Secretariat General, Uppsala, Sweden. pp. 14-50.

Buts, J., De Keyser, N., Kolanowski, J., and Van Hoof, F. 1990. Hormonal regulation of the rat small intestine: responsiveness of villus and crypt cells to insulin during the suckling period and unresponsiveness after weaning. Pediatr. Res. 27: 161-164. doi:10.1203/00006450-199002000-00015. PMID:2179834.

Cabral, R.G., Kent, E.J., Haines, D.M., and Erickson, P.S. 2012. Addition of sodium bicarbonate to either 1 or 2 feedings of colostrum replacer: effect on uptake and rate of absorption of immunoglobulin G in neonatal calves. J. Dairy Sci. 95: 3337-3341. doi:10.3168/jds.2011-5137. PMID:22612967.

Cabral, R.G., Cabral, M.A., Chapman, C.E., Kent, E.J., Haines, D.M., and Erickson, P.S. 2014. Colostrum replacer feeding regiment, addition of sodium bicarbonate, and milk replacer: the combined effects on absorptive efficiency of immunoglobulin G in neonatal calves. J. Dairy Sci. 97: 2291-2296. doi:10.3168/jds.2013-7007. PMID:24534514.

Camp, M.E., Wiley, A.A., Boulos, M.B., Rahman, K.M., Bartol, F.F., and Bagnell, C.A. 2018. Effects of age, nursing, and oral IGF1 supplementation on porcine cervical development. Reproduction, 148: 441-451. doi:10.1530/REP-14-0257. PMID:25074922.

Campbell, P.G., Skaar, T.C., Vega, J.R., and Baumrucker, C.R. 1991. Secretion of insulin-like growth factor-I (IGF-I) and IGFbinding proteins from bovine mammary tissue in vitro. J. Endocrinol. 128: 219-228. doi:10.1677/joe.0.1280219. PMID:1706405.

Cervenak, J., and Kacskovics, I. 2009. The neonatal Fc receptor plays a crucial role in the metabolism of IgG in livestock animals. Vet. Immunol. Immunopathol. 128: 171-177. doi:10.1016/ j.vetimm.2008.10.300. PMID:19027179.

Chernikov, M.P., Lyaiman, M.É., and Nesterin, M.F. 1972. Effect of a combination of proteinase inhibitors on insulin absorption from the small intestine in dogs. Bull. Exp. Biol. Med. 73: 641-643. doi:10.1007/BF00811211. PMID:5050580.
Chigerwe, M., Hagey, J.V., and Aly, S.S. 2015. Determination of neonatal serum immunoglobulin $\mathrm{G}$ concentrations associated with mortality during the first 4 months of life in dairy heifer calves. J. Dairy Res. 82: 400-406. doi:10.1017| s0022029915000503. PMID:26383079.

Coleman, D.N., Murphy, K.D., and Relling, A.E. 2018. Prepartum fatty acid supplementation in sheep. II. Supplementation of eicosapentaenoic acid and docosahexaenoic acid during late gestation alters the fatty acid profile of plasma, colostrum, milk and adipose tissue, and increases lipogenic gene expression of adipose tissue. J. Anim. Sci. 96: 1181-1204. doi:10.1093/ jas/skx013. PMID:29365116.

Conneely, M., Berry, D.P., Murphy, J.P., Lorenz, I., Doherty, M.L., and Kennedy, E. 2014. Effect of feeding colostrum at different volumes and subsequent number of transition milk feed on the serum immunoglobulin $\mathrm{G}$ concentration and health status on dairy calves. J. Dairy Sci. 97: 6991-7000. doi:10.3168/ jds.2013-7494. PMID:25200772.

Contarini, G., Povolo, M., Pelizzola, V., Monti, L., Bruni, A., Passolungo, L., et al. 2014. Bovine colostrum: changes in lipid constituents in the first 5 days after parturition. J. Dairy Sci. 97: 5065-5072. doi:10.3168/jds.2013-7517. PMID:24931528.

Corley, L.D., Staley, T.E., Bush, L.J., and Jones, E.W. 1977. Influence of colostrum on transepithelial movement of Escherichia coli 055. J. Dairy Sci. 60: 1416-1421. doi:10.3168/ jds.s0022-0302(77)84046-0. PMID:334811.

Coroian, A., Erler, S., Matea, C.T., Mireşan, V., Răducu, C., Bele, C., and Coroian, C.O. 2013. Seasonal changes of buffalo colostrum, physiochemical parameters, fatty acids, and cholesterol variation. Chem. Cent. J. 7: 40-49. doi:10.1186/1752153X-7-40. PMID:23442377.

Dai, Y., Ivell, R., and Anand-Ivell, R. 2017a. Theca cell INSL3 and steroids together orchestrate the growing bovine antral follicle. Front. Physiol. 8: 1033-1047. doi:10.3389/ fphys.2017.01033.

Dai, Y., Ivell, R., Liu, X., Janowski, D., and Anand-Ivell, R. 2017b. Relaxin-family peptide receptors 1 and 2 are fully functional in the bovine. Front. Physiol. 8: 359-370. doi:10.3389/ fphys.2017.00359.

Davis, C.L., and Drackely, J.K. 1998. The development, nutrition, and management of the young calf. Iowa State University Press, Ames, IA, USA.

De Carvalho, C.C.C.R., and Caramujo, M.J. 2018. The various roles of fatty acids. Molecules, 23: 2583-2619. doi:10.3390/ molecules23102583.

Deelen, S.M., Ollivett, T.L., Haines, D.M., and Leslie, K.E. 2014. Evaluation of a Brix refractometer to estimate serum immunoglobulin $\mathrm{G}$ concentration in neonatal dairy calves. J. Dairy Sci. 97: 3838-3844. doi:10.3168/jds.2014-7939.

De Santis, S., Cavalcanti, E., Mastronardi, M., Jirillo, E., and Chieppa, M. 2015. Nutritional keys for intestinal barrier modulation. Front. Immunol. 6: 612. doi:10.3389/ fimmu.2015.00612. PMID:26697008.

Desjardins-Morrissette, M., van Niekerk, J.K., Haines, D., Sugino, T., Oba, M., and Steele, M.A. 2018. The effect of tube versus bottle feeding colostrum on immunoglobulin $\mathrm{G}$ absorption, abomasal emptying, and plasma hormone concentrations in newborn calves. J. Dairy Sci. 101: 1-12. doi:10.3168/jds.2017-13904. PMID:29454696.

Dewell, R.D., Hungerford, L.L., Keen, J.E., Laegreid, W.W., Griffin, D.D., Ripp, G.P., and Grotelueschen, D.M. 2006. Association of neonatal serum immunoglobulin G1 concentration with health and performance in beef calves. J. Am. Vet. Med. Assoc. 228: 914-921. doi:10.2460/javma.228.6.914. PMID:16536707.

Donovan, S.M., Chao, J.C.J., Zijlstra, R.T., and Odle, J. 1997. Orally administered iodinated recombinant human insulin-like growth factor-I ( ${ }^{125}$ I-rhIGF-I) is poorly absorbed by the 
newborn piglet. J. Pediatr. Gastroenterol. Nutr. 24: 174-182. doi:10.1097/00005176-199702000-00011. PMID:9106104.

Dunn, A., Ashfield, A., Earley, B., Welsh, M., Gordon, A., and Morrison, S.J. 2017. Evaluation of factors associated with immunoglobulin G, fat, protein, and lactose concentrations in bovine colostrum and colostrum management practices in grassland-based dairy systems in Northern Ireland. J. Daiy Sci. 100(3): 2068-2079. doi:10.3168/jds.2016-11724. PMID:28088405.

Elizondo-Salazar, J.A., and Heinrichs, A.J. 2009. Feeding heattreated colostrum to neonatal dairy heifers: Effects on growth characteristics and blood parameters. J. Dairy Sci. 92: 3265-3273. doi:10.3168/jds.2008-1667. PMID:19528603.

Fahey, M.J., Fischer, A.J., Steele, M.A., and Greenwood, S.L. 2020. Characterization of the colostrum and transition milk proteomes from primparous and multiparous Holstein dairy cows. J. Dairy Sci. 103: 1993-2005. doi:10.3168/jds.2019-17094. PMID:31837789.

Feeney, S., Gerlach, J.Q., Slattery, H., Kilcoyne, M., Hickey, R.M., and Joshi, L. 2019. Lectin microarray profiling and monosaccharide analysis of bovine milk immunoglobulin $\mathrm{G}$ oligosaccharides during the first 10 days of lactation. Food Sci. Nutr. 7: 1564-1572. doi:10.1002/fsn3.950. PMID:31139369.

Fellows, I.W., Evans, D.F., Bennett, T., Macdonald, I.A., Clark, A.G., and Bloom, S.R. 1987. The effect of insulin-induced hypoglycemia on gastrointestinal motility in man. Clin. Sci. 72: 743-748. doi:10.1042/cs0720743. PMID:3297471.

Fernandez, L.A., and Berenguer, J. 2000. Secretion and assembly of regular surface structures in Gram-negative bacteria. FEMS Microbiol. Rev. 24: 21-44. doi:10.1111/j.15746976.2000.tb00531.x. PMID:10640597.

Filteau, V., Bouchard, E., Fecteau, G., Dutil, L., and DuTremblay, D. 2003. Health status and risk factors associated with failure of passive transfer of immunity in newborn beef calves in Quebec. Can. Vet. J. 44: 907-913. PMID:14664353.

Fischer-Tlustos, A.J., Hertogs, K., Van Niekerk, J.K., Nagorske, M., Haines, D.M., and Steele, M.A. 2020a. Oligosaccharide concentrations in colostrum, transition milk, and mature milk of primi- and multi-parous Holstein cows during the first week of lactation. J. Dairy Sci. 103: 3683-3695. doi:10.3168/jds.2019-17357. PMID:32037163.

Fischer-Tlustos, A.J., Yoo, R.K.H., Garner, A.M., Bakker, S.A., Lyons, S.M., Zandberg, W.F., and Steele, M.A. $2020 b$. Sialylated oligosaccharide and sialic acid profile of colostrum, transition milk and whole milk in primiparous and multiparous Holstein dairy cattle. J Dairy Sci. 103(Suppl. 1): 31.

Fischer, A.J., Malmuthuge, N., Guan, L.L., and Steele, M.A. 2018a. Short communication: the effect of heat treatment of bovine colostrum on the concentration of oligosaccharides in colostrum and in the intestine of neonatal male Holstein calves. J. Dairy Sci. 101: 401-407. doi:10.3168/jds.2017-13533.

Fischer, A.J., Song, Y., He, Z., Haines, D.M., Guan, L.L., and Steele, M.A. 2018b. Effect of delaying colostrum feeding on passive transfer and intestinal bacterial colonization in neonatal male Holstein calves. J. Dairy Sci. 101: 3099-3109. doi:10.3168/jds.2017-13397. PMID:29397179.

Frankshun, A.-L., Ho, T.-Y., Reimer, D.C., Chen, J., Lasano, S., Steinetz, B.G., et al. 2011. Characterization and biological activity of relaxin in porcine milk. Reproduction, 141: 373-380. doi:10.1530/REP-10-0401. PMID:21177955.

Furman-Fratczak, K., Rzasa, A., and Stefaniak, T. 2011. The influence of colostral immunoglobulin concentration in heifer calves' serum on their health and growth. J. Dairy Sci. 94: 5536-5543. doi:10.3168/jds.2010-3253. PMID:22032377.

Garcia, M., Shin, J.H., Schlaefli, A., Greco, L.F., Maunsell, F.P., Thatcher, W.W., et al. 2015. Increasing intake of essential fatty acids from milk replacer benefits performance, immune responses, and health of preweaned Holstein calves. J. Dairy Sci. 98: 458-477. doi:10.3168/jds.2014-8384. PMID:25465563.

Garcia, M., Greco, L.F., Block, E., Santos, J.E.P., Thatcher, W.W., and Staples, C.R. 2016. Programming effect of dietary fatty acids on performance of Holstein heifers from birth through first lactation. Anim. Feed Sci. Technol. 222: 64-74. doi:10.1016/j.anifeedsci.2016.10.003.

Garcia, M., Greco, L.F., Favoreto, M.G., Marsola, R.S., Martins, L.T., Bisinotto, R.S., et al. 2014. Effect of supplementing fat to pregnant nonlactating cows on colostral fatty acid profile and passive immunity of the newborn calf. J. Dairy Sci. 97: 392-405. doi:10.3168/jds.2013-7086. PMID:24239079.

Gauthier, S.F., Pouliot, Y., and Maubois, J.-L. 2006. Growth factors from bovine milk and colostrum: composition, extraction and biological activities. Dairy Sci. Technol. 86: 99-125. doi:10.1051/lait:2005048.

Gay, C.C. 1983. Failure of passive transfer of colostral immunoglobulins and neonatal disease in calves: a review. Proc. 4th Int. Symp. Neonatal Dis. Vet. Infect. Dis. Org., Saskatoon, SK, Canada. pp. 346-364.

Gelsinger, S.L., Jones, C.M., and Heinrichs, A.J. 2015. Effect of colostrum heat treatment and bacterial population on immunoglobulin $\mathrm{G}$ absorption and health of neonatal calves. J. Dairy Sci. 98: 4640-4645. doi:10.3168/jds.2014-8790. PMID:25935243.

Gelsinger, S.L., Gray, S.M., Jones, C.M., and Heinrichs, A.J. 2014. Heat treatment of colostrum increases immunoglobulin G absorption efficiency in high-, medium-, and low-quality colostrum. J. Dairy Sci. 97: 2355-2360. doi:10.3168/jds.20137374. PMID:24508433.

George, A.F., Rahman, K.M., Miller, D.J., Wiley, A.A., Camp, M.E., Bartol, F.F., and Bagnell, C.A. 2018. Effects of colostrum, feeding method and oral IGF1 on porcine uterine development. Reproduction, 155: 259-271. doi:10.1530/REP-17-0658. PMID:29339452.

Georgiev, I.P., Georgieva, T.M., Pfaffl, M., Hammon, H.M., and Blum, J.W. 2003. Insulin-like growth factors and insulin receptors in intestinal mucosa of neonatal calves. J. Endocrinol. 176: 121-132. doi:10.1677/joe.0.1760121. PMID:12525256.

Georgieva, T.M., Georgiev, I.P., Ontsouka, E., Hammon, H.M., Pfaffl, M.W., and Blum, J.W. 2003. Abundance of message for insulin-like growth factors-I and -II and for receptors for growth hormone, insulin-like growth factors-I and -II, and insulin in the intestine and liver of pre- and full-term calves. J. Anim. Sci. 81: 2294-2300. doi:10.2527/2003.8192294x. PMID:12968705.

Gil, A., and Sanchez-Medina, F. 1981. Acid-soluble nucleotides of a cow's, goat's and sheep's milks, at different stage of lactation. J. Dairy Res. 48: 35-44. doi:10.1017/s0022029900021427. PMID:7196410.

Gill, B.D., Indyk, H.E., and Manley-Harris, M. 2011. Determination of total potentially available nucleosides in bovine milk. Int. Dairy J. 21: 34-41. doi:10.1016/j.idairyj. 2010.07.004.

Gill, R.K., Mahmood, S., and Nagpaul, J.P. 1999. Functional role of sialic acid in IgG binding to microvillus membranes in neonatal rate intestine. Biol. Neonate, 76: 55-64. doi:10.1159/ 000014131. PMID:10364639.

Gluckman, P.D., Butler, J.H., and Elliott, T.B. 1983. The ontogeny of somatotropic binding sites in ovine hepatic membranes. J. Endocrinol. 112: 1607-1612. doi:10.1210/endo-112-5-1607. PMID:6131814.

Godden, S. 2008. Colostrum management for dairy calves. Vet. Clin. North Am. Food Anim. Pract. 24: 19-39. doi:10.1016/ j.cvfa.2007.10.005. PMID:18299030. 
Godden, S.M., Haines, D.M., Konkol, K., and Peterson, J. 2009. Improving passive transfer of immunoglobulins in calves. II: Interaction between feeding method and volume of colostrum fed. J. Dairy Sci. 92: 1758-1764. doi:10.3168/jds.2008-1847. PMID:19307658.

Godden, S.M., Smolenski, D.J., Donahue, M., Oakes, J.M., Bey, R., Wells, S., et al. 2012. Heat-treated colostrum and reduced morbidity in preweaned dairy calves: results of a randomized trial and examination of mechanisms of effectiveness. J. Dairy Sci. 95: 4029-4040. doi:10.3168/jds.2011-5275. PMID:22720957.

Godden, S.M., Lombard, J.E., and Woolums, A.R. 2019. Colostrum management for dairy calves. Vet. Clin. Food Anim. Pract. 35(3): 535-556. doi:10.1016/j.cvfa.2019.07.005.

Gooden, J.M., Brandon, M.R., Hartmann, P.E., and Lascelles, A.K. 1971. Factors affecting lipid output and flow of thoracic duct lymph in newborn calves. Aust. J. Biol. Sci. 24: 1309-1318. doi:10.1071/BI9711309. PMID:5163488.

Górka, P., Kowalski, Z.M., Zabielski, R., and Guilloteau, P. 2018. Invited review: use of butyrate to promote gastrointestinal tract development in calves. J. Dairy Sci. 101: 4785-4800. doi:10.3168/jds.2017-14086. PMID:29525310.

Grütter, R., and Blum, J.W. 1991. Insulin and glucose in neonatal calves after peroral insulin and intravenous glucose administration. Reprod. Nutr. Dev. 31: 389-397. doi:10.1051/rnd: 19910405. PMID:1747197.

Gulliksen, S.M., Lie, K.I., Sølverød, L., and Østerås, O. 2008. Risk factors associated with colostrum quality in Norwegian dairy cows. J. Dairy Sci. 91: 704-712. doi:10.3168/jds.2007-0450. PMID:18218758.

Guy, M.A., McFadden, T.B., Cockrell, D.C., and Besser, T.E. 1994a Regulation of colostrum formation in beef and dairy cows. J. Dairy Sci. 77: 3002-3007. doi:10.3168/jds.s0022-0302(94) 77241-6. PMID:7836587.

Guy, M.A., McFadden, T.B., Cockrell, D.C., and Besser, T.E. $1994 b$. Effects of unilateral prepartum milking on concentrations of immunoglobulin G1 and prolactin in colostrum. J. Dairy Sci. 77: 3584-3591. doi:10.3168/jds.s0022-0302(94)77302-1. PMID:7699136.

Hadorn, U., Hammon, H., Bruckmaier, R.M., and Blum, J.W. 1997. Delaying colostrum intake by one day has important effects on metabolic traits an on gastrointestinal and metabolic hormones in neonatal calves. J. Nutr. 127: 2011-2023. doi:10.1093/jn/127.10.2011. PMID:9311959.

Halleran, J., Sylvester, H.K., and Foster, D.M. 2017. Short communication: apparent efficiency of colostral immunoglobulin G absorption in Holstein heifers. J. Dairy Sci. 100: 3282-3286. doi:10.3168/jds.2016-11904. PMID:28189325.

Hammon, H.M., Zanker, I.A., and Blum, J.W. 2000. Delayed colostrum feeding affects IGF-I and insulin plasma concentrations in neonatal calves. J. Dairy Sci. 83: 85-92. doi:10.3168/jds.S0022-0302(00)74859-4. PMID:10659968.

Hammon, H.M., Steinhoff-Wagner, J., Flor, J., Schönhusen, U., and Metges, C.C. 2013. Lactation biology symposium: role of colostrum and colostrum components on glucose metabolism in neonatal calves. J. Anim. Sci. 91: 685-695. doi:10.2527/jas2012-5758. PMID:23100594.

Hammon, H.M., Liermann, W., Frieten, D., and Koch, C. 2020. Review: importance of colostrum supply and milk feeding intensity on gastrointestinal and systemic development in calves. Animal, 14: S133-S143. doi:10.1017/S1731119003148. PMID:32024575.

Hare, K., Pletts, S., Pyo, J., Haines, D., Guan, L.L., and Steele, M.A. 2020. Feeding colostrum or a 1:1 colostrum:whole milk mixture for $3 \mathrm{~d}$ postnatal increases serum immunoglobulin $\mathrm{G}$ and apparent IgG persistency in Holstein bulls. J. Dairy Sci. 103: 11833-11843. doi:10.3168/jds.2020-18558.
Hare, K.S., Hertogs, K., Fischer, A., Vahmani, P., Dugan, M.E.R., and Steele, M. 2019a. Omega-3 and -6 fatty acids are more abundant in colostrum than transition and whole milk. Abst. J. Dairy Sci. 102(Suppl. 1): 209.

Hare, K.S., Wood, K.M., Fitzsimmons, C., and Penner, G.B. $2019 b$. Oversupplying metabolizable protein in late gestation for beef cattle: effects on postpartum ruminal fermentation, blood metabolites, skeletal muscle catabolism, colostrum composition, milk yield and composition, and calf growth performance. J. Anim. Sci. 97: 437-455. doi:10.1093/jas/sky413.

Hiltz, R.L., and Laarman, A.H. 2019. Effect of butyrate on passive transfer of immunity in dairy calves. J. Dairy Sci. 102: 1-8. doi:10.3168/jds.2018-15555. PMID:30879822.

Hoffman, F.C., and Opazo, J.C. 2011. Evolution of the relaxin/ insulin-like gene family in placental mammals: implications for its early evolution. J. Mol. Evol. 72: 72-79. doi:10.1007| s00239-010-9403-6. PMID:21082170.

Honan, M.C., Fahey, M.J., Fischer-Tlustos, A.J., Steele, M.A., and Greenwood, S.L. 2020. Shifts in the Holstein dairy cow milk fat globule membrane proteome that occur during the first week of lactation are affected by parity. J. Anim. Sci. Biotechnol. 11: 81. doi:10.1186/s40104-020-00478-7. PMID:32695335.

Huizing, M. 2005. Disease mechanisms associated with mutations of the GNE gene. Drug Discov. Today Dis. Mech. 2: 519-527. doi:10.1016/j.ddmec.2005.11.003.

Huo, Y.J., Wang, T., Xu, R.J., Macdonald, S., Liu, G., and Shi, F. 2006. Dietary insulin affects leucine aminopeptidase, growth hormone, insulin-like growth factor I and insulin receptors in the intestinal mucosa of neonatal pigs. Biol. Neonate, 89: 265-273. doi:10.1159/000091482. PMID:16479091.

Izumi, H., Kosaka, N., Shimizu, T., Sekine, K., Ochiya, T., and Takase, M. 2012. Bovine milk contains microRNA and messenger RNA that are stable under degradative conditions. J. Dairy Sci. 95: 4831-4841. doi:10.3168/jds.2012-5489. PMID:22916887.

Izumi, H., Kosaka, N., Shimizu, T., Sekine, K., Ochiya, T., and Takase, M. 2014. Time-dependent expression profiles of microRNAs and mRNAs in rat milk whey. PLoS ONE, 9: e88843. doi:10.1371/journal.pone.0088843. PMID:24533154.

James, R.E., Polan, C.E., and Cummins, K.A. 1981. Influence of administered indigenous microorganisms on uptake of iodine-125 gamma-globulin in vivo by intestinal segments of neonatal calves. J. Dairy Sci. 64: 52-61. doi:10.3168/jds.s00220302(81)82528-3. PMID:6167599.

Jaster, E.H. 2005. Evaluation of quality, quantity, and timing of colostrum feeding on immunoglobulin $G$ absorption in Jersey calves. J. Dairy Sci. 88: 296-302. doi:10.3168/jds.s00220302(05)72687-4. PMID:15591392.

Jehle, P.M., Fussagaenger, R.D., Blum, W.F., Angelus, N.K., Hoeflich, A., Wolf, E., and Jungwirth, R.J. 1999. Differential autocrine regulation of intestinal epithelial cell proliferation and differentiation by insulin-like growth factor (IGF) system components. Horm. Metab. Res. 31: 97-102. doi:10.1055/ s-2007-978705. PMID:10226788.

Ji, X., Li, X., Ma, Y., and Li, D. 2017. Differences in proteomic profiles of milk fat globule membrane in yak and cow milk. Food Chem. 221: 1822-1827. doi:10.1016/j.foodchem.2016. 10.097. PMID:27979168.

Jochims, K., Kaup, F.J., Drommer, W., and Pickel, M. 1994. An immunoelectron microscopic investigation of colostral IgG absorption across the intestine of newborn calves. Res. Vet. Sci. 57: 75-80. doi:10.1016/0034-5288(94)90085-X. PMID:7973097.

Jolazadeh, A.R., Mohammadabadi, T., Dehghan-bandaky, M., Chaji, M., and Garcia, M. 2019a. Effect of supplementing calcium salts of n-3 and n-6 fatty acid to pregnant nonlactating cows on colostrum composition, milk yield, and 
reproductive performance of dairy cows. Anim. Feed Sci. Technol. 247: 127-140. doi:10.1016/j.anifeedsci.2018.11.010.

Jolazadeh, A.R., Mohammadabadi, T., Dehghan-bandaky, M., Chaji, M., and Garcia, M. 2019b. Effect of supplementation fat during the last 3 weeks of uterine life and the preweaning period on performance, ruminal fermentation, blood metabolites, passive immunity and health of the newborn calf. Br. J. Nutr. 122: 1346-1358. doi:10.1017/S0007114519002174. PMID:31482771.

Jouan, P.-N., Pouliot, Y., Gauthier, S.F., and Laforest, J.-P. 2006. Hormones in bovine milk and milk products: a survey. Int. Dairy J. 16: 1408-1414. doi:10.1016/j.idairyj.2006.06.007.

Kadkhoday, A., Riasi, A., Alikhani, M., Dehghan-Banadaky, M., and Kowsar, R. 2017. Effects of fact sources and dietary $C_{18: 2}$ to $C_{18: 3}$ fatty acids ratio on growth performance, ruminal fermentation and some blood components of Holstein calves. Livest. Sci. 204: 71-77. doi:10.1016/j.livsci.2017.08.012.

Karcher, E.L., Hill, T.M., Bateman, H.G., II., Sclotterbeck, R.L., Vito, N., Sordillo, L.M., and VanderHaar, M.J. 2014. Comparison of supplementation of n-3 fatty acids from fish and flax oil on cytokine gene expression and growth of milk-fed Holstein calves. J. Dairy Sci. 97: 2329-2337. doi:10.3168/jds.2013-7160. PMID:24485693.

Karlsson, K.A. 1995. Microbial recognition of target-cell glycoconjugates. Curr. Opin. Struct. Biol. 5: 622-635. doi:10.1016/ 0959-440x(95)80054-9. PMID:8574698.

Kehoe, S.I., Jayarao, B.M., and Heinrichs, A.J. 2007. A survey of bovine colostrum composition and colostrum management practices on Pennsylvania dairy farms. J. Dairy Sci. 90: 4108-4116. doi:10.3168/jds.2007-0040. PMID:17699028.

Kidron, M., Bar-On, H., Berry, E.M., and Ziv, E. 1982. The absorption of insulin from various regions of the rat intestine. Life Sci. 31: 2837-2841. doi:10.1016/0024-3205(82)90673-7. PMID:6761532.

Kirovski, D.K., Lazarević, M., Baričević-Jones, I., Nedić, O., Masnikosa, R., and Nikolić, J.A. 2008. Effects of peroral insulin and glucose on circulating insulin-like growth factor-I, its binding proteins and thyroid hormones in neonatal calves. Can. J. Vet. Res. 72: 253-258. PMID:18505189.

Klusmeyer, T.H., Fitzgerald, A.C., Fabellar, A.C., Ballam, J.M., Cady, R.A., and Vicini, J.L. 2009. Effect of recombinant bovine somatotropin and a shortened or no dry period on the performance of lactating dairy cows. J. Dairy Sci. 92: 5503-5511. doi:10.3168/jds.2009-2390. PMID:19841213.

Lago, A., Socha, M., Geiger, A., Cook, D., Silva-del-Río, N., Blanc, C., et al. 2018. Efficacy of colostrum replacer versus maternal colostrum on immunological status, health, and growth of preweaned dairy calves. J. Dairy Sci. 101: 1344-1354. doi:10.3168/jds.2017-13032. PMID:29153521.

Le, A., Barton, L.D., Saunders, J.T., and Zhang, Q.A. 2011. Exploration of bovine milk proteome in colostral and mature whey using an ion exchange approach. J. Proteome Res. 10: 692-704. doi:10.1021/pr100884z. PMID:21077624.

Leece, J.G. 1973. Effect of dietary regimen in cessation of uptake of macromolecules by piglet intestinal epithelium (closure) and transport into blood. J. Nutr. 103: 751-756. doi:10.1093/ jn/103.5.751. PMID:4710087.

Leiber, F., Hochstrasser, R., Wettstein, H.-R., and Kreuzer, M. 2011. Feeding transition cows with oilseeds: effects on fatty acid composition of adipose tissue, colostrum and milk. Livest. Sci. 138: 1-12. doi:10.1016/j.livsci.2010.11.016.

Liang, G., Malmuthuge, N., Guan, L.L., and Griebel, P. 2015. Model systems to analyze the role of miRNAs and commensal microflora in bovine mucosal immune system development. Mol. Immunol. 66(1): 57-67. doi:10.1016/j.molimm.2014.10.014. PMID:25467799.

Lombard, J., Urie, N., Garry, F., Godden, S., Quigley, J., and Earleywine, T. 2020. Consensus recommendations on calf- and her-level passive immunity in dairy calves in the United States. J. Dairy Sci. 103: 7611-7624. doi:10.3168/jds.201917955. PMID:32448583.

Lopez, A.J., Jones, C.M., Geiger, A.J., and Heinrichs, A.J. 2020. Comparison of immunoglobulin $\mathrm{G}$ absorption in calves fed maternal colostrum, a commercial whey-based colostrum replacer, or supplemented maternal colostrum. J. Dairy Sci. 103: 4838-4845. doi:10.3168/jds.2019-17949. PMID:32197853.

Ma, T., O’Hara, E., Song, Y., Fischer, A., He, Z., Steele, M.A., and Guan, L.L. 2019. Altered mucosa-associated microbiota in the ileum and colon of neonatal calves in response to delayed first colostrum feeding. J. Dairy Sci. 102: 7073-7086. doi:10.3168/jds.2018-16130. PMID:31202657.

Malmuthuge, N., Chen, Y., Liang, G., Goonewardene, L.A., and Guan, L.L. 2015. Heat-treated colostrum feeding promotes beneficial bacteria colonization in the small intestine of neonatal calves. J. Dairy Sci. 98: 8044-8053. doi:10.3168/jds.20159607. PMID:26342981.

Malone, L., Opazo, J.C., Ryan, P.L., and Hoffmann, F.G. 2017. Progressive erosion of the Relaxin1 gene in bovids. Gen. Comp. Endocrinol. 252: 12-17. doi:10.1016/j.ygcen.2017.07.011. PMID:28733228.

Malven, P.V., Head, H.H., and Collier, R.J. 1987. Periparturient changes in secretion and mammary uptake of insulin and in concentrations of insulin and insulin-like growth factors in milk of dairy cows. J. Dairy Sci. 70: 2254-2265. doi:10.3168/jds.S0022-0302(87)80285-0. PMID:3320114.

Mann, S., Leal Yepes, F.A., Overton, T.R., Lock, A.L., Lamb, S.V., Wakshlag, J.J., and Nydam, D.V. 2016. Effect of dry period dietary energy level in dairy cattle on volume, concentrations of immunoglobulin $\mathrm{G}$, insulin, and fatty acid composition of colostrum. J. Dairy Sci. 99: 1515-1526. doi:10.3168/ jds.2015-9926. PMID:26709187.

Marcobal, A., Barboza, M., Sonnenburg, E.D., Pudlo, N., Martens, E.C., Desai, P., et al. 2011. Bacteroides in the infant gut consume milk oligosaccharides via mucus-utilization pathways. Cell Host Microbe, 10: 507-514. doi:10.1016/ j.chom.2011.10.007. PMID:22036470.

Marcobal, A., Barboza, M., Froehlich, J.W., Block, D.E., German, J.B., Lebrilla, C.B., and Mills, D.A. 2010. Consumption of human milk oligosaccharides by gut-related microbes. J. Agric. Food Chem. 58: 5334-5340. doi:10.1021/jf9044205. PMID:20394371.

Marques, R.S., Cooke, R.F., Rodrigues, M.C., Brandão, A.P., Schubach, K.M., Lippolis, K.D., et al. 2017. Effects of supplementing calcium salts of polyunsaturated fatty acids to lategestating beef cows on performance and physiological responses of the offspring. J. Anim. Sci. 95: 5347-5357. doi:10.2527/jas2017.1606. PMID:29293770.

Martin-Sosa, S., Martin, M.J., and Hueso, P. 2002. The sialylated fraction of milk oligosaccharides is partially responsible for binding to enterotoxigenic and uropathogenic Escherichia coli in human strains. J. Nutr. 132: 3067-3072. doi:10.1093/jn/ 131.10.3067. PMID:12368397.

Martin-Sosa, S., Martin, M.J., Garcia-Pardo, L.A., and Hueso, P. 2003. Sialyloligosaccharides in human and bovine milk and in infant formulas: variations with the progression of lactation. J. Dairy Sci. 86: 52-59. doi:10.3168/jds.s0022-0302(03) 73583-8. PMID:12613848.

Martin, M-J., Martin-Sosa, S., and Hueso, P. 2002. Binding of milk oligosaccharides by several enterotoxigenic Escherichia coli strains isolated from calves. Glycoconj. J. 19: 5-11. doi:10.1023/A:1022572628891. PMID:12652075.

Mashiko, T., Nagafuchi, S., Kanbe, M., Obara, Y., Hagawa, Y., Takahashi, T., and Katoh, K. 2009. Effects of dietary uridine 5'-monophosphate on immune responses in newborn calves. J. Anim. Sci. 87(3): 1042-1047. doi:10.2527/jas.2008-1004. PMID:19228994. 
Mayasari, N., de Vries Reilingh, G., Nieuwland, M.G., Remmelink, G.J., Parmentier, H.K., Kemp, B., and van Knegsel, A.T. 2015. Effect of maternal dry period length on colostrum immunoglobulin content and on natural and specific antibody titers in calves. J. Dairy Sci. 98: 3969-3979. doi:10.3168/jds.2014-8753. PMID:25828658.

McDonnell, R.P., O’Doherty, J.V., Earley, B., Clarke, A.M., and Kenny, D.A. 2019. Effect of supplementation with n-3 polyunsaturated fatty acids and/or $\beta$-glucans on performance, feeding behaviour and immune status of Holstein Friesian bull calves during the pre- and post-weaning periods. J. Anim. Sci. Biotechnol. 10: 7-24. doi:10.1186/s40104-019-0317-x.

McGee, M., and Earley, B. 2019. Review: passive immunity in beef-suckler calves. Animal, 13: 810-825. doi:10.1017| s1751731118003026. PMID:30458893.

McGrath, B.A., Fox, P.F., McSweeney, P.L.H., and Kelly, A.L. 2016. Composition and properties of bovine colostrum: a review. Dairy Sci. Technol. 96: 133-158. doi:10.1007/s13594-015-0258-x.

McGuirk, S.M., and Collins, M. 2004. Managing the production, storage, and delivery of colostrum. Vet. Clin. North Am. Food Anim. Pract. 20: 593-603. doi:10.1016/j.cvfa.2004. 06.005. PMID:15471626.

McJarrow, P., and van Amelsfort-Schoonbeek, J. 2004. Bovine sialyl oligosaccharides: seasonal variation in their concentrations in milk and a comparison of the colostrums of Jersey and Friesian cows. Int. Dairy J. 15: 571-579. doi:10.1016/ j.idairyj.2003.11.006.

Menard, D., Malo, C., and Calvert, R. 1981. Insulin accelerates the development of intestinal brush border hydrolytic activities of suckling mice. Dev. Biol. 85: 150-155. doi:10.1016/ 0012-1606(81)90244-X. PMID:6114004.

Moallem, U. 2018. Invited review: roles of dietary n-3 fatty acids in performance, milk fat composition, and reproductive and immune systems in dairy cattle. J. Dairy Sci. 101: 8641-8661. doi:10.3168/jds.2018-14772. PMID:30100509.

Mokhber-Dezfooli, M.R., Nouri, M., Rasekh, M., and Constable, P.D. 2012. Effect of abomasal emptying rate on the apparent efficiency of colostral immunoglobulin $\mathrm{G}$ absorption in neonatal Holstein-Friesian calves. J. Dairy Sci. 95: 6740-6749. doi:10.3168/jds.2012-5926. PMID:22981576.

Morin, D.E., McCoy, G.C., and Hurley, W.L. 1997. The effects of quality, quantity, and timing of colostrum feeding and addition of a dried colostrum supplement on immunoglobulin $G_{1}$ absorption in Holstein bull calves. J. Diary Sci. 80: 747-753. doi:10.3168/jds.s0022-0302(97)75994-0. PMID:9149969.

Morishita, M.I., Morishita, K., Takayama, K., Machida, Y., and Nagai, T. 1993. Site-dependent effect of aprotinin, sodium caprate, $\mathrm{Na}_{2}$ EDTA and sodium glycocholate on intestinal absorption of insulin. Biol. Pharm. Bull. 16: 68-72. doi:10.1248/bpb.16.68. PMID:7690292.

Morrill, K.M., Conrad, E., Lago, A., Campbell, J., Quigley, J., and Tyler, H. 2012. Nationwide evaluation of quality and composition of colostrum on dairy farms in the United States. J. Dairy Sci. 95: 3997-4005. doi:10.3168/jds.2011-5174. PMID:22720954.

Mosinger, B., Placer, Z., and Koldovsky, O. 1959. Passage of insulin through the wall of the gastrointestinal tract of the infant rat. Nature, 184: 1245-1246. doi:10.1038/1841245a0. PMID:14424567.

Nakamura, T., Kawase, H., Kimura, K., Watanabe, Y., and Ohtani, M. 2003. Concentrations of sialyloligosaccharides in bovine colostrum and milk during the prepartum and early lactation. J. Dairy Sci. 86(4): 1315-1321. doi:10.3168/jds.S00220302(03)73715-1. PMID:12741556.

Ninonuevo, M.R., Park, Y., Yin, H., Zhang, J., Ward, R.E., Clowers, B.H., et al. 2006. A strategy for annotating the human milk glycome. J. Agric. Food Chem. 54(20): 7471-7480. doi:10.1021/jf0615810. PMID:17002410.
Nissen, A., Andersen, P.H., Bendixen, E., Ingvartsen, K.L., and Røntved, C.M. 2017. Colostrum and milk protein rankings and ratios of importance to neonatal calf health using a proteomics approach. J. Dairy Sci. 100: 2711-2728. doi:10.3168/ jds.2016-11722. PMID:28189329.

Noble, R.C., Shand, J.H., and Christie, W.W. 1985. Synthesis of C20 and C22 polyunsaturated fatty acids by the placenta of the sheep. Biol. Neonate, 47: 333-338. doi:10.1159/000242136. PMID:4027296.

Noble, R.C., Shand, J.H., Drummond, J.T., and Moore, J.H. 1978. "Protected" polyunsaturated fatty acid in the diet of the ewe and the essential fatty acid status of the neonatal lamb. J. Nutr. 108: 1868-1876. doi:10.1093/jn/108.11.1868. PMID:712431.

O’Callaghan, T.F., O’Donovan, M., Murphy, J.P., Surgue, K., Mannion, D., McCarthy, W.P., et al. 2020. Evolution of the bovine milk fatty acid profile - from colostrum to milk five days post parturition. Int. Dairy J. 104: 104655-104663. doi:10.1016/j.idairyj.2020.104655.

O’Hara, E.A., Bage, R., Emanuelson, U., and Holtenius, K. 2019. Effects of dry period length on metabolic status, fertility, udder health and colostrum production in 2 cow breeds. J. Dairy Sci. 102:595-606. doi:10.3168/jds.2018-14873. PMID:30343909.

Ollivier-Bousquet, M. 1998. Transferrin and prolactin transcytosis in the lactating mammary epithelial cell. J. Mammary Gland Biol. Neoplasia, 3: 303-313. doi:10.1023/a: 1018767528017. PMID:10819516.

Ontsouka, E.C., Albrecht, C., and Bruckmaier, R.M. 2016. Invited review: growth-promoting effects of colostrum in calves based on interaction with intestinal cell surface receptors and receptor-like transporters. J. Dairy Sci. 99: 4111-4123. doi:10.3168/jds.2015-9741. PMID:26874414.

Opgenorth, J., Sordillo, L.M., Lock, A.L., Gandy, J.C., and VandeHaar, M.J. 2020a. Colostrum supplementation with n-3 fatty acids alters plasma polyunsaturated fatty acids and inflammatory mediators in newborn calves. J. Dairy Sci. 103(12): 11676-11688. doi:10.3168/jds.2019-18045. PMID:33041038.

Opgenorth, J., Sordillo, L.M., and VandeHaar, M.J. $2020 b$. Colostrum supplementation with $\mathrm{n}-3$ fatty acids and $\omega$-tocopherol alters plasma polyunsaturated fatty acid profile and decreases an indicator of oxidative stress in newborn calves. J. Dairy Sci. 103: 3545-3553. doi:10.3168/jds.201917380. PMID:32008774.

Opgenorth, J., Sordillo, L.M., Gandy, J.C., and VandeHaar, M.J. 2020 c. Colostrum supplementation with n-3 fatty acids does not alter calf outcome on a healthy commercial farm. J. Dairy Sci. 103: 11689-11696. doi:10.3168/jds.2019-18046. PMID:33041039.

Osaka, I., Matsui, Y., and Terada, F. 2014. Effect of the mass of immunoglobulin (Ig)G intake and age at first colostrum feeding on serum IgG concentration in Holstein calves. J. Dairy Sci. 97(10): 6608-6612. doi:10.3168/jds.2013-7571. PMID:25064644.

Pakkanen, R., and Aalto, J. 1997. Growth factors and antimicrobial factors of bovine colostrum. Int. Dairy J. 7(5): 285-297. doi:10.1016/s0958-6946(97)00022-8.

Parrish, D.B., Wise, G.H., Hughes, J.S., and Atkeson, F.W. 1950. Properties of the colostrum of the dairy cow. V. Yield, specific gravity and concentrations of total solids and its various components of colostrum and early milk. J. Dairy Sci. 33: 457-465. doi:10.3168/jds.s0022-0302(50)91921-7.

Payne, E. 1978. Fatty acid composition of tissue phospholipids of the foetal calf and neonatal lamb, deer calf and piglet as compared with the cow, sheep, deer and pig. Br. J. Nutr. 39: 45-52. doi:10.1079/BJN19780010. PMID:619977. 
Pentsuk, N., and van der Laan, J.W. 2009. An interspecies comparison of placental antibody transfer: new insights into developmental toxicity testing of monoclonal antibodies. Birth Def. Res. B Dev. Reprod. Toxicol. 86(4): 328-344. doi:10.1002/bdrb.20201.

Peri, S., Kulkarni, A., Feyertag, F., Berninsone, P.M., and AlvarezPonce, D. 2018. Phylogenetic distribution of CMP-Neu5Ac hydroxylase (CMAH), the enzyme synthesizing the proinflammatory human zenoantigen Neu5Gc. Gen. Biol. Evol. 101(1): 207-219. doi:10.1093/gbe/evx251.

Piechotta, M., Mysegades, W., Ligges, U., Lilienthal, J., Hoeflich, A., Miyamoto, A., and Bollwein, H. 2015. Antepartal insulinlike growth factor 1 and insulin-like growth factor binding protein 2 concentrations are indicative of ketosis in dairy cows. J. Dairy Sci. 98: 3100-3109. doi:10.3168/jds.2014-8885. PMID:25704973.

Pierce, A.E., Risdall, P.C., and Shaw, B. 1964. Absorption of orally administered insulin by the newly born calf. J. Physiol. 171: 203-215. doi:10.1113/jphysiol.1964.sp007372. PMID:14191475.

Plaza-Diaz, J., Fontana, L., and Gil, A. 2018. Human milk oligosaccharides and immune system development. Nutrients, 10(8): 1038. doi:10.3390/nu10081038. PMID:30096792.

Prosser, C.G., Fleet, I.R., Davis, A.J., and Heap, R.B. 1991. Mechanism of secretion of plasma insulin-like growth factor-I into milk of lactating goats. J. Endocrinol. 131: 459-466. doi:10.1677/joe.0.1310459. PMID:1783889.

Pyo, J., Hare, K., Pletts, S., Inabu, Y., Haines, D., Sugino, T., et al. 2020. Feeding colostrum or a 1:1 colostrum:milk mixture for 3 days postnatal increases small intestinal development and minimally influences plasma glucagon-like peptide-2 and serum insulin-like growth factor-1 concentrations in Holstein bull calves. J. Dairy Sci. 103: 4236-4251. doi:10.3168/ jds.2019-17219. PMID:32171512.

Quigley, J.D., Martin, K.R., III, Dowlen, H.H., Wallis, L.B., and Lamar, K. 1994. Immunoglobulin concentration, specific gravity, and nitrogen fractions of colostrum from Jersey cattle. J. Dairy Sci. 77: 264-269. doi:10.3168/jds.S0022-0302(94) 76950-2. PMID:8120194.

Quigley, J.D., Lago, A., Chapman, C., Erickson, P., and Polo, J. 2013. Evaluation of the Brix refractometer to estimate immunoglobulin G concentration in bovine colostrum. J. Dairy Sci. 96: 1148-1155. doi:10.3168/jds.2012-5823. PMID:23200468.

Quigley, J.D., III, and Drewry, J.J. 1998. Nutrient and immunity transfer from cow to calf pre and postcalving. J. Dairy Sci. 81: 2779-2790. doi:10.3168/jds.s0022-0302(98)75836-9. PMID:9812284.

Raboisson, D., Trilliat, P., and Cahuzac, C. 2016. Failure of passive immune transfer in calves: a meta-analysis on the consequences and assessment of the economic impact. PLoS ONE, 11: e0150452. doi:10.1371/journal.pone.0150452. PMID:26986832.

Radford, D., Hare, K., Penner, G., and Wood, K. 2018. PSXII-10 Providing excess metabolizable protein prior to calving shifts the protein composition of colostrum and early postcolostrum serum proteomic profiles in neonatal beef calves. J. Anim. Sci. 96(Suppl. 3): 264. doi:10.1093/jas/sky404.579.

Rasmussen, J.T. 2009. Bioactivity of milk fat globule membrane proteins. Aust. J. Dairy Technol. 64: 63-67.

Rauprich, A.B., Hammon, H.M., and Blum, J.W. 2000. Influence of feeding different amounts of first colostrum on metabolic, endocrine, and health status and on growth performance in neonatal calves. J. Anim. Sci. 78: 896-908. doi:10.2527/ 2000.784896x. PMID:10784179.

Reinhardt, T.A., and Lippolis, J.D. 2008. Developmental changes in the milk fat globule membrane proteome during the transition from colostrum to milk. J Dairy Sci. 91: 2307-2318. doi:10.3168/jds.2007-0952. PMID:18487653.
Renaud, D.L., Steele, M.A., Genore, R., Roche, S.M., and Winder, C.B. 2020. Passive immunity and colostrum management practices on Ontario dairy farms and auction facilities: a cross-sectional study. J. Dairy Sci. 103: 8369-8377. doi:10.3168/jds.2020-18572. PMID:32684475.

Ricks, R.E., Cook, E.K., and Long, N.M. 2020. Effects of supplementing ruminal-bypass unsaturated fatty acids during late gestation on beef cow and calf serum and colostrum fatty acids, transfer of passive immunity and cow and calf performance. Appl. Anim. Sci. 36: 271-284. doi:10.15232/aas.201901900.

Robinson, R.C., Poulsen, N.A., Colet, E., Duchene, C., Larsen, L.B., and Barile, D. 2019. Profiling of aminoxy TMT-labeled bovine milk oligosaccharides reveals substantial variation in oligosaccharide abundance between dairy cattle breeds. Sci. Rep. 9: 5465. doi:10.1038/s41598-019-41956-x.

Robison, J.D., Stott, G.H., and DeNise, S.K. 1988. Effects of passive immunity on growth and survival in the dairy heifer. J. Dairy Sci. 71: 1283-1287. doi:10.3168/jds.s0022-0302(88) 79684-8. PMID:3135297.

Roche, P.J., Crawford, R.J., and Tregear, G.W. 1993. A single-copy relaxin-like gene sequence is present in sheep. Mol. Cell. Endocrinol. 91: 21-28. doi:10.1016/0303-7207(93)90250-N. PMID:7682520.

Roffler, B., Fäh, A., Sauter, S.N., Hammon, H.M., Gallman, P., Brem, G., and Blum, J.W. 2003. Intestinal morphology, epithelial cell proliferation, and absorptive capacity in neonatal calves fed milk-born insulin-like growth factor-I or a colostrum extract. J. Dairy Sci. 86: 1797-1806. doi:10.3168/ jds.S0022-0302(03)73765-5. PMID:12778590.

Roy, J.H.B. 1990. The calf, 5th ed. Vol. 1. Butterworths, London, UK.

Russo, A., Stevens, J.E., Chen, R., Gentilcore, D., Burnet, R., Horowitz, M., and Jones, K.L. 2005. Insulin-induced hypoglycemia accelerates gastric emptying of solids and liquid in long-standing type 1 diabetes. J. Clin. Endocrinol. Metab. 90: 4489-4495. doi:10.1219/jc.2005-0513. PMID:15899955.

Sadri, H., Steinhoff-Wagner, J., Hammon, H.M., Bruckmaier, R.M., Görs, S., and Sauerwein, H. 2017. Mammalian target of rapamycin signaling and ubiquitin proteasome-related gene expression in 3 different skeletal muscles of colostrumversus formula-fed calves. J. Dairy Sci. 100: 9428-9441. doi:10.3168/jds.2017-12857. PMID:28918148.

Saldana, D.J., Gelsinger, S.L., Jones, C.M., and Heinrichs, A.J. 2019. Effect of different heating times of high-, medium-, and low-quality colostrum on immunoglobulin $\mathrm{G}$ absorption in dairy calves. J. Dairy Sci. 102: 2068-2074. doi:10.3168/ jds.2018-15542. PMID:30660413.

Salehi, R., and Ambrose, D.J. 2017. Prepartum maternal diets supplemented with oilseeds alter the fatty acid profile in bovine neonatal plasma possibly through reduced placental expression of fatty acid transport protein 4 and fatty acid translocase. Reprod. Fertil. Dev. 29: 1846-1855. doi:10.1017| RD15476.

Salehi, R., Ambrose, D.J., and Oba, M. 2016. Short communication: effects of prepartum diets supplemented with rolled oilseeds on Brix values and fatty acid profile of colostrum. J. Dairy Sci. 99: 3598-3601. doi:10.3168/jds.2015-10189. PMID:26971161.

Sasaki, M., Davis, C.L., and Larson, B.L. 1976. Production and turnover of IgG1 and IgG2 immunoglobulins in the bovine around parturition. J. Dairy Sci. 59: 2046-2055. doi:10.3168/ jds.S0022-0302(76)84486-4. PMID:1010882.

Satchell, L., Glister, C., Bleach, E.C., Glencross, R.G., Bicknell, A.B., Dai, Y., et al. 2013. Ovarian expression of insulin-like peptide 3 (INSL3) and its receptor (RXFP2) during development of bovine antral follicles and corpora lutea and measurement of circulating INSL3 levels during synchronized 
estrous cycles. Endocrinology, 154: 1897-1906. doi:10.1210/ en.2012-2232.

Schäff, C.T., Gruse, J., Maciej, J., Mielenz, M., Wirthgen, E., Hoeflich, A., et al. 2016. Effects of feeding milk replacer ad libitum or in restricted amounts for the first five weeks of life on the growth, metabolic adaptation, and immune status of newborn calves. PLoS ONE, 11: e0168974. doi:10.1371/ journal.pone.0168974. PMID:28036351.

Schvarcz, E., Palmer, M., Aman, J., and Berne, C. 1995. Hypoglycemia increases the gastric emptying rate in healthy subjects. Diabet. Care, 18: 674-676. doi:10.2337/diacare.18.5.674.

Schvarcz, E., Palmer, M., Aman, J., Lindkvist, B., and Beckman, K.W. 1993. Hypoglycaemia increases gastric emptying rate in patients with type 1 diabetes mellitus. Diabet. Med. 10: 660-663. doi:10.1111/j.1464-5491.1993.tb00141.x. PMID:8403829.

Schwab, C., and Ganzle, M. 2011. Lactic acid bacteria fermentation of human milk oligosaccharide components, human milk oligosaccharides and galactooligosaccharides. FEMS Microbiol. Lett. 315: 141-148. doi:10.1111/j.15746968.2010.02185.x. PMID:21175746.

Sejrsen, K., Pedersen, L.O., Vestergaard, M., and Purup, S. 2001. Biological activity of bovine milk: contribution of IGF-1 and IGF binding proteins. Livest. Prod. Sci. 70: 79-85. doi:10.1016/ S0301-6226(01)00199-3.

Shah, U., Dickinson, B.L., Blumberg, R.S., Simister, N.E., Lencer, W.I., and Walker, W.A. 2003. Distribution of the IgG Fc receptor, FcRn, in the human fetal intestine. Pediatr. Res. 53: 295-301. doi:10.1203/00006450-200302000-00015. PMID:12538789.

Sharifi, K., Grunberg, W., Soroori, S., Mohri, M., and AhrariKhafi, M.S. 2009. Assessment of the acetaminophen absorption test as a diagnostic tool for the evaluation of the reticular groove reflex in lambs. Am. J. Vet. Res. 70: 820-825. doi:10.2460/ajvr.70.7.820. PMID:19566466.

Shen, W.-H., and Xu, R.-J. 2000. Gastrointestinal stability and absorption of insulin in suckling pigs. Comp. Biochem. Physiol. Part A, 125: 389-401. doi:10.1016/S1095-6433(00) 00169-0.

Shivley, C.B., Lombard, J.E., Urie, N.J., Haines, D.M., Sargent, R., Kopral, C.A., et al. 2018. Preweaned heifer management on US dairy operations: Part II. Factors associated with colostrum quality and passive transfer status of dairy heifer calves. J. Dairy Sci. 101: 9185-9198. doi:10.3168/jds.201714008. PMID:29908806.

Shoshani, E., Rozen, S., and Doekes, J.J. 2014. Effect of a short dry period on milk yield and content, colostrum quality, fertility, and metabolic status of Holstein cows. J. Dairy Sci. 97: 2909-2922. doi:10.3168/jds.2013-7733. PMID:24630671.

Shulman, R. 1990. Oral insulin increases small intestinal mass and disaccharidase activity in the newborn miniature pig. Pediatr. Res. 28: 171-175. doi:10.1203/00006450-19900800000018. PMID:1697670.

Simister, N.E., and Rees, A.R. 1985. Isolation and characterization of an Fc receptor from neonatal rat small intestine. Eur. J. Immunol. 15: 733-738. doi:10.1002/eji.1830150718. PMID:2988974.

Simon, P., Kedinger, M., Raul, F., Grenier, J.F., and Haffen, K. 1982. Organ culture of suckling rate intestine: comparative study of various hormones on brush border enzymes. In Vitro, 18: 330-346. doi:10.1007/bf02796332.

Sischo, W.M., Short, D.M., Geissler, M., Bunyatratchata, A., and Barile, D. 2016. Comparative composition, diversity, and abundance of oligosaccharides in early lactation milk from commercial dairy and beef cows. J. Dairy Sci. 100: 3883-3892. doi:10.3168/jds.2016-12388.

Skaar, T.C., Baumrucker, C.R., Deaver, D.R., and Blum, J.W. 1994. Diet effects and ontogeny of alterations of circulating insulin-like growth factor binding proteins in newborn dairy calves. J. Anim. Sci. 72: 421-427. doi:10.2527/1994.722421x. PMID:7512546.

Skrzypek, T., Szymańczyck, S., Ferenc, K., Kazimierczak, W., Szczepaniak, K., and Zabielski, R. 2018. The contribution of vacuolated foetal-type enterocytes in the process of maturation of the small intestine in piglets. Invited review. J. Anim. Feed Sci. 27: 187-201. doi:10.22358/jafs/94167/2018.

Smilowitz, J.A., Lebrilla, C.B., Mills, D.A., German, J.B., and Freeman, S.L. 2014. Breast milk oligosaccharides: structurefunction relationship in the neonate. Annu. Rev. Nutr. 34: 143-169. PMID:24850388.

Song, Y., Malmuthuge, N., Li, F., and Guan, L.L. 2019. Colostrum feeding shapes the hindgut microbiota of dairy calves during the first $12 \mathrm{~h}$ of life. FEMS Microbiol. Ecol. 95(1). doi:10.1093/ femsec/fiy203. PMID:30307547.

Sparks, A.L., Kirkpatrick, J.G., Chamberlain, C.S., Waldner, D., and Spicer, L.J. 2003. Insulin-like growth factor-1 and its binding proteins in colostrum compared to measures in serum of Holstein neonates. J. Dairy Sci. 86: 2022-2029. doi:10.3168/ jds.S0022-0302(03)73791-6. PMID:12836938.

Śpitalniak-Bajerska, K., Szummy, A., Pogoda-Sewerniak, K., and Kupczyński, R. 2020. Effects of n-3 fatty acids on growth, antioxidant status, and immunity of preweaned dairy calves. J. Dairy Sci. 103: 2864-2876. doi:10.3168/jds.2019-17001. PMID:31954570.

Staley, T.E., and Bush, L.J. 1985. Receptor mechanisms of the neonatal intestine and their relationship to immunoglobulin absorption and disease. J. Dairy Sci. 68: 184-205. doi:10.3168/ jds.s0022-0302(85)80812-2. PMID:3884680.

Stott, G.H., Marx, D.B., Menfee, B.E., and Nightengale, G.T.1979. Colostral immunoglobulin transfer in calves: I: Period of absorption. J. Dairy Sci. 62: 1632-1638. doi:10.3168/jds.s00220302(79)83472-4. PMID:536479.

Sun, Q., Chen, X., Yu, J., Zen, K., Zhang, C.Y., and Li, L. 2013. Immune modulatory function of abundant immune-related microRNAs in microvesicles from bovine colostrum. Protein Cell, 4: 197-210. doi:10.1007/s13238-013-2119-9. PMID:23483481.

Swan, H., Godden, S., Bey, R., Wells, S., Fetrow, J., and ChesterJones, H. 2007. Passive transfer of immunoglobulin $G$ and preweaning health in Holstein calves fed a commercial colostrum replacer. J. Dairy Sci. 90: 3857-3866. doi:10.3168/ jds.2007-0152. PMID:17638996.

Takimori, S., Shimaoka, H., Furukawa, J-I., Yamashita, T., Amano, M., Fujitani, N., et al. 2011. Alteration of the $\mathrm{N}$-glycome of bovine milk glycoproteins during early lactation. FEBS J. 278: 3769-3781. doi:10.1111/j.1742-4658.2011.08299.x.

Tao, N., DePeters, E.J., German, J.B., Grimm, R., and Lebrilla, C.B. 2009. Variations in bovine milk oligosaccharides during early and middle lactation stages analyzed by highperformance liquid chromatography-chip/mass spectrometry. J. Dairy Sci. 92: 2991-3001. doi:10.3168/jds.2008-1642. PMID:19528576.

Todd, C.G., McGee, M., Tiernan, K., Crosson, P., O’Riordan, E., McClure, J., et al. 2018. An observational study on passive immunity in Irish suckler beef and dairy calves: Tests for failure of passive transfer of immunity and associations with health and performance. Prev. Vet. Med. 159: 182-195. doi:10.1016/j.prevetmed.2018.07.014. PMID:30314781.

Tucker, H.A. 1981. Physiological control of mammary growth, lactogenesis, and lactation. J Dairy Sci. 64: 1403-1421. doi:10.3168/jds.s0022-0302(81)82711-7. PMID:6268672.

Tyler, J.W., Hancock, D.D., Parish, S.M., Rea, D.E., Besser, T.E., Sanders, S.G., and Wilson, L.K. 1996. Evaluation of 3 assays for failure of passive transfer in calves. J. Vet. Intern. Med. 10: 304-307. doi:10.1111/j.1939-1676.1996.tb02067.x. PMID:8884716.

Tzaban, S., Massol, R.H., Yen, E., Hamman, W., Frank, S.R., Lapierre, L.A., et al. The recycling and transcytotic pathways 
for IgG transport by FcRn are distinct and display an inherent polarity. 2009. J. Cell Biol. 185: 673-684. doi:10.1083/ jcb.200809122.

Urie, N.J., Lombard, J.E., Shivley, C.B., Kopral, C.A., Adams, A.E., Earleywine, T.J., et al. 2018a. Preweaned heifer management on US dairy operations: Part V. Factors associated with morbidity and mortality in preweaned dairy heifer calves. J. Dairy Sci. 101: 9229-9244. doi:10.3168/jds.2017-14019. PMID:29935825.

Urie, N.J., Lombard, J.E., Shivley, C.B., Kopral, C.A., Adams, A.E., Earleywine, T.J., et al. 2018b. Preweaned heifer management on US dairy operations: Part I: Descriptive characteristics of preweaned heifer raising operations. J. Dairy Sci. 101: 9168-9184. doi:10.3168/jds.2017-14010. PMID:29908815.

Vacher, P.-Y., Bestetti, G., and Blum, J.W. 1995. Insulin-like growth factor I absorption in the jejunum of neonatal calves. Biol. Neonate, 68: 354-367. doi:10.1159/000244256. PMID:8835090.

Vermorel, M., Dardillat, C., Vernet, J., Saido, and Deminge, C.. 1983. Energy metabolism and thermoregulation in the newborn calf. Ann. Rech. Vét. 14: 382-389. PMID:6677179.

Vicaretti, S.D., Mohtarudin, N.A., Garner, A.M., and Zandberg, W.F. 2018. Capillary electrophoresis analysis of bovine milk oligosaccharides permits and assessment of the influence of diet and the discovery of nine abundant sulfated analogues. J. Agric. Food Chem. 66: 8574-8583. doi:10.1021/acs.jafc. 8b01041. PMID:29745223.

Waldner, C.L., and Rosengren, L.B. 2009. Factors associated with serum immunoglobulin levels in beef calves from Alberta and Saskatchewan and association between passive transfer and health outcomes. Can. Vet. J. 50: 275-281. PMID:19436479.

Weaver, D.M., Tyler, J.W., VanMetre, D.C., Hostetler, D.E., and Barrington, G.M. 2000. Passive transfer of colostral immunoglobulins in calves. J. Vet. Intern. Med. 14: 569-577. doi:10.1111/j.1939-1676.2000.tb02278.x. PMID:11110376.

Weber, C.R. 2012. Dynamic properties of the tight junction barrier. Ann. N. Y. Acad. Sci. 1257: 77-84. doi:10.1111/j.17496632.2012.06528.x. PMID:22671592.

Wells, S.J., Dargatz, D.A., and Ott, S.L. 1996. Factors associated with mortality to 21 days of life in dairy heifers in the United States. Prev. Vet. Med. 29: 9-19. doi: 10.1016/S01675877(96)01061-6.

Whitmore, T.J., Trengove, N.J., Graham, D.F., and Hartmann, P.E. 2012. Analysis of insulin in human breast milk in mothers with Type 1 and Type 2 Diabetes mellitus. Int. J. Endocrinol. 2012: 296368. doi:10.1155/2012/296368.

Whitney, R.M., Brunner, J.R., Ebner, K.E., Farrell, H.M., Jr, Josephson, R.V., Morr, C.V., and Swaisgood, H.E. 1976. Nomenclature of the proteins of cow's milk: fourth revision. J. Dairy Sci. 59(5): 795-815. doi:10.3168/jds.s0022-0302(76) 84280-4. PMID:57970.
Wickramasinghe, S., Hua, S., Rincon, G., Isla-Trejo, A., Bruce German, J., Lebrilla, C.B., and Medrano, J.F. 2011. Transcriptome profiling of bovine milk oligosaccharide metabolism genes using RNA-sepequening. PLoS ONE, 6(4): e18895. doi:10.1371/journal.pone.0018895. PMID:21541029.

Winder, C.B., Bauman, C.A., Duffield, T.F., Barkema, H.W., Keefe, G.P., Dubuc, J., et al. 2018. Canadian National Dairy Study: Heifer calf management. J. Dairy Sci. 101: 10565-10579. doi:10.3168/jds.2018-14680. PMID:30172400.

Winger, K., Gay, C.C., and Besser, T.E. 1995. Immunoglobulin G1 transfer into induced mammary secretions: the effect of dexamethasone. J. Dairy Sci. 78: 1306-1309. doi:10.3168/jds.s00220302(95)76751-0. PMID:7673519.

Worden, L.C., Erickson, M.G., Gramer, S., Tap, C., Ylioja, C., Trottier, N., et al. 2018. Short communication: Decreasing the dietary ratio n-6 to n-3 fatty acids increases the n-3 concentration of peripheral blood mononuclear cells in weaned Holstein heifer calves. J. Dairy Sci. 101: 1227-1233. doi:10.3168/jds.2017-12696. PMID:29174150.

Xu, R.J., and Wang, T. 1996. Gastrointestinal absorption of insulin-like growth factor-I in neonatal pigs. J. Pediatr. Gastroenterol. Nutr. 23: 430-437. doi:10.1097/00005176199611000-00013. PMID:8956182.

Yang, Y., Zheng, N., Zhao, X., Zhang, Y., Han, R., Ma, L., et al. 2015. Proteomic characterization and comparison of mammalian milk fat globule proteomes by iTRAQ analysis. J. Proteom. 116: 34-43. doi:10.1016/j.jprot.2014.12.017.

Yu, Z.-T., Chen, C., and Newburg, D.S. 2013. Utilization of major fucosylated and sialylated human milk oligosaccharides by isolated human gut microbes. Glycobiology, 23(11): 1281-1292. doi:10.1093/glycob/cwt065. PMID:24013960.

Zandkarimi, F., Vanegas, J., Fern, X., Maier, C.S., and Bobe, G. 2018. Metabotypes with elevated protein and lipid catabolism and inflammation precede clinical mastitis in prepartal transition dairy cows. J. Dairy Sci. 101: 5531-5548. doi:10.3168/ jds.2017-13977. PMID:29573799.

Zhou, R., Gong, A.Y., Eischeid, A.N., and Chen, X.M. 2012. miR27b targets KSRP to coordinate TLR4-mediated epithelial defense against Cryptosporidium parvum infection. PLoS Pathog. 8: e1002702. doi:10.1371/journal.ppat.1002702. PMID:22615562.

Zinicola, M., and Bicalho, R.C. 2019. Association of peripartum plasma insulin concentration with milk production colostrum insulin levels, and plasma metabolites of Holstein cows. J. Dairy Sci. 102: 1473-1482. doi:10.3168/jds.2017-14029. PMID:30471907.

Zivkovic, A.M., German, J.B., Lebrilla, C.B., and Mills, D.A. 2011. Human milk glycobiome and its impact on the infant gastrointestinal microbiota. Proc. Natl. Acad. Sci. U. S. A. 108(1): 4653-4658. doi:10.1073/pnas.1000083107. 